\title{
Investigating interconnected fisheries: a coupled model of the lobster and herring fisheries in New England
}

\author{
Sigrid Lehuta ${ }^{\mathrm{a}, 1, *}$,Daniel S. Holland ${ }^{\mathrm{b}}$, Andrew J. Pershing ${ }^{\mathrm{a}, \mathrm{c}}$
}

\begin{abstract}
${ }^{a}$ Gulf of Maine Research Institute, 350 Commercial Street, Portland, ME 04101, USA.
${ }^{b}$ Conservation Biology Division, Northwest Fisheries Science Center, National Marine Fisheries Service, National Oceanic and Atmospheric Administration, 2725 Montlake Blvd. East, Seattle, WA 98112-2097, USA.

${ }^{\mathrm{C}}$ University of Maine School of Marine Sciences, 5706 Aubert Hall, Orono, ME 04469, USA.
\end{abstract}

${ }^{1}$ Present address : Ifremer, unité Ecologie et Modèles pour l'halieutique, rue de l'ile d'Yeu, F-44311 Nantes 03, France.

*: Corresponding author : Sigrid Lehuta, email address : slehuta@ifremer.fr

\begin{abstract}
:
Ostensibly separate fisheries are often linked through ecological, environmental and human mediated processes that can impact their productivity, profitability and resilience; however, managers rarely explicitly account for these linkages. We present a coupled bioeconomic model of the American lobster (Homarus americanus) and Atlantic herring (Clupea harengus) fisheries in the Northeast US. The model builds upon existing stock assessment models and includes key characteristics of both fisheries including size- or age-structured populations, seasonal patterns of lobster exploitation, and seasonal-spatial patterns of herring exploitation. The lobster and herring models are linked through a bait market module that drives behavior of the herring fleet and affects catches, costs and revenues in both fisheries. The model illustrates how changes in management or ecosystem conditions in one fishery can propagate to another. The model suggests that the lobster fishery is robust to declines in herring recruitment and limited changes in the spatial allocation of the herring TAC. However, herring catches and stocks are affected by changes in lobster management that impact effort levels.
\end{abstract}

\section{Résumé:}

Des pêcheries apparemment indépendantes sont souvent connectées au travers de processus écologiques, environnementaux ou par des activités humaines qui peuvent impacter leur productivité, leur profitabilité et leur résilience; Cependant, les gestionnaires prennent rarement en compte de manière explicite les liens entre les pêcheries. Nous présentons un modèle bioéconomique des pêcheries de homard (Homarus americanus) du Maine et de hareng (Clupea harengus) de la côte nord-est des Etats-Unis. Le modèle est basé sur les modèles d'évaluation des deux stocks et inclut les caractéristiques clefs des deux pêcheries. Les modèles de homard et de hareng sont connectés via un module de marché de l'appât, qui conditionne le comportement des flottilles pêchant le hareng et affecte les captures, les coûts et les revenus dans les deux pêcheries. Le model montre comment les changements dans le système de gestion ou les conditions de l'environnement dans l'une des pêcheries se propagent à l'autre. Le modèle suggère que la pêcherie de homard est robuste à un déclin du recrutement du hareng et à des changements limités dans l'allocation spatiale du total admissible des captures de hareng. Cependant, les stocks et captures de hareng peuvent être affectés par des changements dans la gestion du homard. 
Introduction

Fisheries that seem separate are often linked through ecological, environmental, and human mediated processes that can impact their productivity, profitability, and resilience. However, fisheries are typically managed independently, ignoring the linkages between them. Fishery managers generally lack the specific knowledge and models necessary to quantify the processes that link fisheries. Consequently, when attempts are made to adjust management actions to account for interactions between fisheries, managers have little information to evaluate impacts and guide decisions.

Marine ecosystems are complex and dynamic, and modeling is an important tool for exploring the consequences of fishery management actions that can directly or indirectly affect multiple species and fishing fleets. Realistic models that can predict all the actions and reactions within an ecosystem are currently impractical. Single-species models connected through the important natural and human linkages offer a fruitful middle ground. Such models can provide advice at a scale that is directly comparable to that provided by the single-species models currently used to inform management decisions. The linked models can clarify the role that connections with other fisheries and the environment play in altering expected outcomes and management advice relative to that based on current single-species models.

Prior studies have illustrated that technical linkages due to joint production (e.g., Ricker 1958; Paulik et al. 1967; Hannesson 1983) and ecological interactions (Flaaten 1989; Brown et al. 2005) can impact feasible and optimal harvest levels for linked fisheries. Here we investigate the implications of a different type of interdependency that arises when one (primary) fishery is dependent on another (secondary) fishery for bait. The availability of the bait species can constrain catch in the primary fishery, but if retention is not $100 \%$ efficient, bait may also provide a "bioenergetic subsidy," that increases growth of the primary-fishery stock. The demand for bait from the primary fishery can in turn 
affect harvest in the secondary fishery, which may impact not only bait harvesters and sustainability of the bait species but its natural predators as well.

We present a coupled bioeconomic model of the American lobster (Homarus americanus) and Atlantic herring (Clupea harengus) fisheries in the Gulf of Maine and Northeast US region respectively. The lobster fishery is one of the most valuable in the US, and the majority of herring caught in the Northeast US is sold as bait to the lobster fishery. The model includes key characteristics of both fisheries including size- or age-structured populations, seasonal patterns of lobster exploitation, and seasonal-spatial patterns of herring exploitation. At present, these fisheries are assessed and managed, independently, despite linkages between them. We show how changes in recruitment, growth, harvest strategies, or fishing behavior in one fishery can affect outcomes in both.

\section{Background on the Fisheries and Linkages between Them}

The American lobster fishery is currently the most valuable fishery in the New England region with landed value totaling over $\$ 418$ million in 2011(NMFS 2013). About $80 \%$ of New England lobster catch was landed in Maine in recent years. Overall landings have been growing steadily and have more than tripled over the last three decades. However, growth in landings in the last decade has been mainly from the Gulf of Maine and mostly in the state of Maine. Maine landings, which never exceeded 12000 metric tons (mt) prior to 1990 have grown steadily, reaching 55,931 mt in 2012 (MDMR 2013). Though it is a small part of the overall economy, the lobster fishery is an important source of employment in some rural coastal areas of Maine and is integral to Maine's tourism industry and cultural identity.

The lobster fishery is managed jointly by state agencies, the Atlantic States Marine Fisheries Commission (ASMFC) and the US National Marine Fisheries Service. Primary management measures include limited access, gear restrictions, prohibitions on taking ovigerous (termed "berried" in the 
fishery) females, and minimum sizes (as well as maximum size in Maine). Each state limits and manages access in state waters, which extend to 3 miles from shore. States also regulate who can land lobsters in that state, thereby maintaining significant control over lobstering in federal waters beyond 3 miles from shore. The states' ability to control the fishery is bolstered by the ASMFC rule that requires that lobstermen fishing in multiple areas abide by the most restrictive management measures of the areas identified on their permits.

While the lobster fishery in southern New England is declining due to overfishing and shell disease (Pearce and Balcom 2005; Wahle et al. 2009), landings from the northern Gulf of Maine have grown, and the lobster stock appears healthy. Gulf of Maine lobsters that have just molted to legal size make up the vast majority of lobster catch (ASMFC 2009). The biomass of legal size lobster is fished down to about $20 \%$ of its annual peak (after the summer molt) each year. However, recruitment to the fishery has been at record levels in recent years enabling annual catches in the last decade to average three to four times the mean catches between 1950 and 1990 (MDMR 2013).

Minimum and maximum size limits and prohibitions on taking berried females help to ensure conservation of the brood stock, but this does not appear to fully explain the increases in productivity of the stock during the last few decades. There are a variety of explanations for the increased productivity and abundance of the Gulf of Maine lobster stock. A reduction in predation resulting from the decline of groundfish in the Gulf of Maine has been suggested as one of the causes for the increase in abundance (Steneck and Wilson 2001). A reduction in predators may also have resulted in an indirect increase in stock productivity by expanding the suitable habitat for lobster and thereby expanding carrying capacity. Anecdotal evidence suggests that the fishery has expanded into areas where lobsters were not previously fished (Fogarty and Gendron 2004), and experimental work suggests that absence of predators does in fact induce lobsters to move into unprotected habitats to feed (McMahan, 2013). 
Recruitment to the fishery and subsequent landings are driven by levels of settlement of post-larvae (Wahle and Fogarty, 2004). Settlement is dependent on environmental conditions including water temperature, currents, and winds that affect the survival of larvae and post larvae and their dispersion and settlement (Drinkwater et al. 1996; Steneck and Wilson 2001; Wahle et al. 2004; Incze et al. 2006; Pershing et al. 2012). Warming waters can also impact juvenile and adult populations and thus the fishery. The 2012 "ocean heat wave" led to a change in the phenology of the lobster population and contributed to record landings (Mills et al. 2013). The spread of shell disease that has heavily affected more Southern lobster populations, has the potential to affect the Maine fishery dramatically.

Another potential contributor to increased growth of the lobster stock is the large amount of herring bait used in the fishery, much of which is consumed by lobsters that subsequently leave the trap or are returned to the water because they are undersized (Saila et al. 2002; Grabowski et al. 2010). Jury et al. (2001) found that lobsters are able to move in and out of lobster traps, making bait an easy source of food. When traps are rebaited, the uneaten bait is discarded, providing additional feeding opportunities for lobsters and other species. In the Maine lobster fishery, total traps fished averaged about 2 million between 1982 and 1993, and then increased in the 1990s reaching 3.25 million by 2006 (ASMFC 2009). As much as $75000 \mathrm{mt}$ of herring bait was used in the fishery annually in recent years (Grabowski et al. 2010). This is more than twice the average weight of annual Maine lobster landings over the last decade. Grabowski et al. (2010) found that lobster in areas with high trap density grew $15 \%$ faster than lobsters in an adjacent area that was closed to lobstering.

The US Atlantic herring landings have averaged over $80000 \mathrm{mt}$ since 2000, but with a relatively low total value in comparison to the lobster fishery (NMFS 2013). Landings in 2011 totaled $77367 \mathrm{mt}$ with a value of $\$ 24$ million. Herring are primarily caught using purse seine and mid-water trawl gear. Like the lobster fishery, the Atlantic herring fishery has also seen growth in landings in the last few 
decades. Prior to expansion of the US and Canadian EEZs there had been a large offshore fishery for herring on Georges Bank that peaked in 1968 at over $373000 \mathrm{mt}$ but then collapsed in the 1970s (Overholtz et al. 2004). Overall herring landings also peaked in 1968 at $479000 \mathrm{mt}$ (Deroba 2010). Since then, the fishery has been concentrated closer to the coast. The fishery is now managed with a competitively fished total allowable catch (TAC) subdivided between different zones. Licenses are also limited, and spatial measures limit harvesting during spawning and restrict use of trawl gear in some areas at times. Fishing mortality remains low on the overall stock, and the assessed spawning stock biomass for 2011 was $517930 \mathrm{mt}$ and not considered overfished (NFSC 2012). However, the great majority of landings are taken from the inshore component of the stock (NEFMC 2010). Setting the areaspecific TACs for herring is complicated and controversial due to the central role that this species plays in both regional fisheries and the ecosystem - i.e., as bait for lobster and forage for groundfish, large pelagic fish such as bluefin tuna, marine mammals, and birds (Overholtz and Link 2007).

Herring bait accounts for nearly $90 \%$ of bait used in lobster traps in Maine (Driscoll 2008). The lobster fishery in the Gulf of Maine is also the predominant market for herring (Brandt and McEvoy 2006) and has utilized roughly $70 \%$ of the US Atlantic herring catch as bait in recent years (Grabowski et al. 2010). The share of herring landings used for lobster bait has likely approached $80 \%$, as herring landings declined by $20 \%$ in 2007 , while lobster effort did not. A further $45 \%$ reduction in the total allowable catch of herring implemented in 2010 created concern that there would be serious bait shortages which would continue to drive up bait prices.

Due to the absence of other sources of bait available in such large quantities and low prices, the quantity of herring available for bait might be expected to limit lobster harvest (Ryan et al. 2010). The lobster fishery in turn is the primary source of demand for herring. Thus economic or environmental changes in either fishery have the potential to affect outcomes in the other, and economically optimal 
management of the system would almost certainly require coordination. We explore the ecological and economic consequences of the linkages between the herring and lobster fisheries under various regulatory and environmental scenarios.

\section{Materials and Methods}

\section{Overall model description}

We built a linked bio-economic model of the lobster and herring fisheries based on information and models available in literature. The model is composed of four linked modules which are described in more detail below (Figure 1). For each species (lobster and herring) there is a population dynamics module and an economic module. These modules are linked and run on a monthly time step. Modeling the intra-annual distribution of lobster and herring catch and effort is critical because lobster landings are highly concentrated in the late summer and fall, and the catch of herring (and the proportion of catch taken from different sub-stocks) is determined by the monthly bait quantity demanded by the lobster fishery as well as seasonal migrations of herring and management controls that vary over space and time.

The number of lobster vessels fishing each month is the main control variable for the simulation model (i.e. the variable that is adjusted to achieve a given outcome or objective such as profit maximization or rent dissipation). The number of lobster vessels is adjusted by a process which simulates outcomes associated with the behavioral assumptions for the lobster and herring vessels associated with each scenario (described in more detail below). In our base case scenario, the monthly lobster effort levels are fixed at the average levels over the period 1998 to 2007 (table A2). Effort is a complex variable that combines the number of vessels fishing in a given month, pot lifts per boat per day, and number of days per month fished. The monthly quantity of bait demanded depends on this monthly number of boats and the number of traps hauled and bait used per trap which adjusts seasonally. The bait quantity 
demanded is passed to the herring fishery module. The herring fleet then satisfies the demand, if possible, by fishing in the lowest cost area based on distance and herring abundance. This procedure determines the herring removed from each stock area, the corresponding price, and how much if any substitute bait has to be used. We use the average estimated population numbers from 2003 to 2007 for lobster, and from 2004 to 2008 for herring, as starting conditions to initialize the simulations. We ran the simulations for 20 years, and our analysis and interpretation focus on the long-term results. Since the model is deterministic (with no stochastic recruitment or other random variation) the system generally stabilized within 10 years or less in the sense that the estimated size of the lobster fleet is stable. Lobster and herring biomass, fishing effort, catches and other variables continue to vary seasonally, but the seasonal patterns stabilize. The simulations track a large number of variables but we report a more limited set of 11 outputs that are most relevant from a policy standpoint. These include the number of boats involved in the lobster fishery, total economic profit, total opportunity costs of captains' time, total crew wages, wages of a single crew member per day in the lobster fishery, lobster biomass and catch, biomass of Gulf of Maine and Georges Bank herring stocks, total herring catch, and the amount of substitute bait used. Other outputs such as prices, herring TACs, catch of herring per area and stock are tracked and analyzed to provide a better understanding of the processes but are not reported here. All reported outputs reflect values for the final year (year 20) of the simulation.

\section{Population Dynamics Module for Lobster}

The lobster population model is derived from the assessment model for the American lobster stock (Chen and Wilson 2005). It is a size-structured matrix model with 35 size classes ( 53 to $228 \mathrm{~mm}$ ) and two sexes. In accordance with the assessment model, lobsters molt twice a year (in July and October) 
according to sex-specific transition matrices which describes probability of molt (Chen and Wilson 2005). The time step has been modified from the quarterly time step used in the assessment to a monthly time step to match the other components of our model. Size specific parameters of lobster population dynamics (natural mortality, maturity, weight and, selectivity) are inputs of the assessment model (Table A1). Outputs of the assessment model have been used to compute an average value for recruitment (from 1987 to 2007), which is held constant (except for specific scenarios) and distributed across the first three size classes (Table A1).

Fishing mortality in the model is determined by the catch from the economic lobster module (see below). Various parameters (called selectivities) are used to distribute monthly total catch across size and sex classes and to reflect seasonally varying selectivity and retention values determined by legal landing size, conservation measures (release of females carrying eggs), and gear selectivity (Chen and Wilson 2005).

\section{Economic Model for Lobster}

The economic module for lobster, based on Holland (2011), captures seasonal changes in catchability, congestion effects that reduce catch rates when aggregate effort levels increase, effects of changes in fishable biomass on catch rates, and the impact that monthly landings have on lobster price. To make the model tractable we assume a homogeneous fleet though substantial heterogeneity in vessels does exist. An empirically estimated translog catch function (Table A3) predicts monthly catches per vessel day as a function of month of the year, lobster biomass, soak days per trap, number of hauls per trip, bait quantity used and the fleet wide number of trap hauls per month. The translog catch function allows for nonlinearity and interactions between inputs. Total lobster catch per month is then calculated by multiplying catch per vessel day by the number of vessel days fished. 
Holland (2011) estimated the translog lobster catch function using individual level catch and effort data for the period 2001 to 2007, and biomass estimates interpolated from the seasonal results of the assessment model. To account for the integration of the population dynamics module used here, the lobster catch function was re-estimated using a lobster biomass time series interpolated using the population dynamics module of our model (Table A3).

Catch, as well as costs and revenues, in the economic lobster module are determined by monthly fleet size, traps fished per vessel, days fished per month, soak times, and quantity of bait used. Our base-case model sets these based on historical effort levels (see Table A2). Monthly trap soak times (the time each trap remains in the water) are set equal to average soak times estimated from port sampling data ${ }^{2}$ collected between 1998 and 2007. The number of boats participating in the lobster fishery each month is set equal to an estimate of the historical monthly average over 1998-2007 period. The number of traps fished per lobsterman is set at 800 to reflect current regulation, and lobstermen are assumed to haul 250 traps each day they fish. The trap limit, soak time and trap hauls per day together determine the number of days each vessel fishes per month. Bait per trap haul varies between summer and winter months. In the base-case simulation, the regulations and limits on licenses and traps per fisherman are similar to the current system; however, it should be noted that the average effort levels between 1998 and 2007 are well below potential effort levels consistent with full utilization of all authorized licenses and below the most recent effort levels.

Lobster prices are determined by an empirically estimated price function (Holland 2011). The price function determines the monthly price of lobster as a function of monthly landings, so prices fluctuate over the year affecting revenues and profits. The monthly landings prices are also a function of the US-

\footnotetext{
${ }^{2}$ The port sampling data was provided by Carl Wilson from the Maine Department of Marine Resources. This program collects catch and effort data directly from lobstermen as they land their catch. It began in August 1966 and is still in operation. Ten lobster buying locations (dealers buying directly from the fishermen) are selected at random each month, April through December. http://www.maine.gov/dmr/rm/lobster/research.htm\#P
} 
Canadian exchange rate, US quarterly per capita personal income, and the percentage change in US gross domestic product from the prior year. Since we do not attempt to model inflation in costs, we fix these macroeconomic values at 2011 levels (Table A2) so that prices for a given level of monthly landings do not rise over time.

The computation of economic profit deducts from revenues the costs of fuel and bait, crew share, captain opportunity cost of labor, and fixed costs (see Table A2 for cost parameters) ${ }^{3}$. Note that, even if economic profit falls to zero, the captain is assumed to be making a daily income $\$ 150$ per day in addition to paying crew, paying for bait and fuel, and covering fixed costs of $\$ 35,000$ per year. The computation of economic profit does not deduct the opportunity cost of capital or account for depreciation, so we may be overestimating long-term economic profits somewhat.

\section{Population Dynamics Module of Herring}

To reflect the meta-population structure of the Gulf of Maine-Georges Bank herring complex (Overholtz et al. 2004), we define two populations, with respective spawning grounds, migration patterns and vital rates (Table A4 and A5). These populations distribute across four areas that match management areas for the species (area 1A, 1B, 2 and 3 in Figure 2). Five age-classes are modeled from age 2 (recruitment in the fishery) to age $6+$ as in the assessment model. Parameters reflect current understanding of the herring population dynamics and have been either estimated based on survey data (NOAA, 1987-2008; weight), borrowed from the assessment model (Shepherd et al., $2009^{4}$; natural mortality), or found in the literature (migration; NEFMC 2010) (Table A4 and A5). When a parameter such as weight displayed

\footnotetext{
${ }^{3}$ Cost information is derived from a variety of sources. Maintaining consistency with Holland 2011, we use estimates of average fuel use per trap haul from Driscoll (2008), bait use is specified as a function of soak time estimated from the port sampling survey, and estimates of fixed costs are drawn from a fixed cost survey carried out by the National Marine Fisheries Service (2008). We set the opportunity cost of the captain's time at \$15 per hour which was the median hourly wage in Maine in 2009.

${ }^{4}$ The model has been build prior to the 2012 assessment and thus is based on the 2009 assessment model.
} 
variations in time, they were set to their average value over the period 1987-2008. Recruitment is deterministic and set equal to the 1989-2008 average (except for specific scenarios).

The population dynamics module of herring is a spatial age-structured matrix model with a monthly time step. At each time step, the population matrix has three dimensions for stocks, age-classes, and areas. Between two time steps, herring can change class (ageing in January), recruit (at age 2), migrate according to migration matrices (Table A5), be caught or die from natural mortality. The sequence of these events is depicted by equation 1 :

(1) $N_{t}=\left(\operatorname{Mig}_{t}\left(C C_{t} N_{t-1}+R_{t}\right)-C_{t}\right) \exp (-M)$

where $N_{t}$ is the population matrix at time $t ; M i g_{t}$ the migration matrix at time $t ; C C_{t}$, the matrix of class change (ageing) at time $t ; R_{t}$ the recruitment matrix at time $t ; C_{t}$ the matrix of catch at time $t$; and $M$ the natural mortality.

Catch is determined by the catch function from the economic herring module described below. Total catch in an area predicted by that module is distributed across stocks proportional to the respective biomass of each stock, and across age classes according to relative abundance and age-specific proportions derived from catch at age data (Table A4).

\section{Economic Module for Herring}

Over the period 2005-2008, a relatively small fleet of 16 pair trawlers and 9 purse seiners accounted for the great majority of catch of herring in the Northeast U.S. and we base our herring fleet module on this fleet. Regulations and industry agreements ban the use of trawl in area $1 \mathrm{~A}$ from June through September and also prevent significant herring harvest in $1 \mathrm{~A}$ from January to May. Spawning closures are also enforced from August to October in area $1 \mathrm{~A}$. Purse seiners mainly fish in area $1 \mathrm{~A}$ in the summer (June through September) when trawling is banned while trawlers follow the fish in its migrations (Table 
A5). For the period 2010-2012, the fishery is further regulated by a TAC which is set according to the assessed biomass and $F_{\text {MSY }}$ of herring (NEFMC 2010). The global TAC is then allocated spatially to four management areas (Figure 2) in order to limit the fishing pressure on the Gulf of Maine component of the metapopulation (equation 2).

(2) $T A C=\left(\right.$ Biomass $_{\text {january }} F_{M S Y}$ Buffer $\left._{\text {scient. }}\right)-$ CanCatch

where $F_{m s y}$ is $0.24 ;$ Buffer $r_{\text {scient. }}$ is 0.6 , buffer to account for scientific uncertainty; CanCatch: $14800 \mathrm{MT}$, corresponding to the estimate of catch by the Canadian fisheries (average Canadian catch from 19992008, NEFMC, 2010). The Scientific and Statistical Committee (2009) initially advised a buffer of 0.6, and we use 0.6 here for convenience when setting TACs in the model; The reference points and SSC recommendations which have been modified following the 2012 assessment, are not considered here. Herring catch is constrained by the area-specific TACs, seasonal area closures, and gear restrictions. However, we do not assume that TACs are fully utilized. Rather the quantity demanded for lobster bait, in conjunction with herring fishery regulations and the costs of catching herring from different areas each month determine monthly harvest from each area.

The herring fleet is assumed to attempt to supply the quantity of lobster bait demanded in a costminimizing way. While herring can be frozen and stored allowing some bait demand to be satisfied through catches from previous months, we assume this remains minimal and do not attempt to include it in the model. The following decision tree is observed each month to determine the areas where herring fishermen will operate and how much catch is taken:

1) Gear choice and area availability: because it is more cost-effective, pair trawl is assumed to be used everywhere except in area $1 \mathrm{~A}$ during the ban (June through September). In the model, we extended the trawl ban through October, to account for the limitation of access due to 
spawning closures from August to October. According to the regulation and industry agreements, area $1 \mathrm{~A}$ is effectively closed to fishing from January to May.

2) Ranking of areas: harvest costs per unit of catch are computed for each area, and areas are ranked according to the cost of supplying bait including both the harvest costs and transport costs to Maine.

3) TAC and effort checking: the areas are fished successively from lowest to highest cost according the harvest cost rankings established above. Catch is taken from the lowest cost area until either the TAC in that area is reached, the effort limitation for the month is reached or total bait demand is satisfied. If an area TAC is reached before bait demand is satisfied catch is taken from the next cheapest area.

Harvest costs by area are a function of catch per unit effort (CPUE). A non-linear regression (software $\mathrm{R}$ cran) was used to fit CPUE functions for each area and gear (Table A7). The relationship proposed by Hilborn and Walters (1992) for anchoveta is adapted to schooling species since CPUE stays high even at low biomass levels (equation 3):

(3) $C P U E_{g, a, t}=\frac{\left(a B_{a, t}\right)}{\left(1+b B_{a, t}\right)}$

where $C P U E_{g, a, t}$ is the catch day at sea for gear $g$, in area $a$ at time $t$ and $B_{a, t}$ is the biomass of herring in area $a$, at time $t . B_{a, t}$ values were taken from the annual assessment and the spring and fall abundance indices of the bottom trawl surveys which are used to distribute biomass over areas for the first and last halves of the calendar year. CPUE for the regressions was derived from logbook data for the period 2005 to 2008 . The data were filtered to retain trips that landed more than $95 \%$ of herring to avoid including trips where other species may have been targeted as well. Effort was computed as days at sea. 
Given estimates of catch per day at sea, harvest cost per unit of catch can be computed by dividing cost costs. Average fixed costs and variable costs per trip (fuel, damage, food, supplies) are calculated by gear type from data collected by the Northeast Fishery Observer Program run by Northeast Fishery Science Center (NEFSC) and the Social Science branch of the NEFSC (NMFS 2008) (Table A8). Transportation costs are estimated as the costs of shipping herring from the landing port to Portland, Maine. Herring are landed all along the US east coast from Wanchese (NC) to Jonesport (ME). The landing port usually depends on the fishing area, thus transportation costs also depend on fishing area. For each fishing area, an average shipping distance was computed as the average distance from each port to Portland, ME weighted by the frequency of visits to the port (derived from logbook data). Assuming that shipping from New Jersey costs $0.06 \$ / \mathrm{lb}$ (Jennie Bichrest, Purseline Bait), the cost for each fishing area was derived by scaling that cost for each port in proportion to its distance from Portland, ME relative to the distance from New Jersey (Table A9). Since the lobster model is not spatially explicit, we use distance from herring landings ports to Portland, ME because it is a primary landing port for herring caught in $1 \mathrm{~A}$, and herring from other areas would go through Portland. The transport costs added to the herring are quite small ranging from $\$ 0.01$ per pound for area $1 \mathrm{~A}$ to $\$ 0.027$ for area 2.

\section{Linking the Lobster and Herring Modules}

Price of herring is a key link between the herring and lobster models as it impacts profitability as well as the lobster effort and catch in the simulations scenarios where effort is set to maximize profit or dissipate economic profits. The bait price that lobstermen actually pay in the simulations is determined by the cost of harvesting and transporting the fish to Maine plus a $\$ 0.15 / \mathrm{lb}$ margin for the bait processor/dealer. Lobstermen are assumed to switch to a substitute bait (e.g., menhaden) when the 
price of herring bait exceeds $\$ 0.30 / \mathrm{lb}$, the price of the substitute. We assume that the substitute bait has a perfectly elastic supply and thus can satisfy all excess bait demand at a constant price of $\$ 0.30 / \mathrm{lb}$. The substitute price of $\$ 0.30 / \mathrm{lb}$ assumes an ex-vessel price of menhaden of $\$ 0.09 / \mathrm{lb}$, transport costs of $0.06 \$ / \mathrm{lb}$ and the same a $\$ 0.15 / \mathrm{lb}$ margin for the bait processor/dealer.

To determine the price the lobster fishery pays for herring for bait, we assume perfect competition in the bait market. Herring fishermen are considered price takers and thus are assumed to choose to fish in the area where the harvest costs per pound are the lowest and where fishing is not forbidden by regulation as described in the previous section. We further assume that the revenue they make from selling herring just covers their expenses (including a share of fixed costs). Note that the expenses include wages for the captain and crew, and thus, that individuals in the fishery still derive income from fishing. The assumption about herring pricing is based on the fact that there are many vessels competing for a share of the TAC and additional vessels with valid licenses would enter the fishery were it profitable to do. This should limit the ability of the fishery participants to command a price in excess of their costs. Under these assumptions, it is possible to compute the corresponding price for herring in each area, each month as a function of herring biomass and gear type (equations 4 to 7 ).

(4) $\operatorname{Rev}_{d a y}=p C P U E$

(5) Costs $_{\text {day }}=C_{\text {variable }}+C_{\text {fixed day }}+C_{\text {crew }}$

(6) $C_{\text {crew }}=\operatorname{CS}\left(\operatorname{Rev} v_{\text {day }}-C_{\text {variable }}\right)$

Assuming null profit:

(7) Costs $_{d a y}=\operatorname{Rev}_{\text {day }}$ and $p=\frac{\left(C_{\text {variable }}(1-C S)+C_{\text {fixed day }}\right)}{(C P U E(1-C S))}$ 


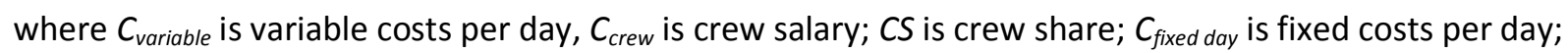
Costs $_{d a y}$ is total costs per day; $\operatorname{Rev}_{d a y}$ is revenue per day; $p$ : ex-vessel herring price and CPUE is catch per unit of effort (i.e., per day).

To account for fixed costs, we assumed that each trip should cover a proportion of the annual fixed costs. We computed fixed cost per day assuming an average of 130 days of fishing per year, which is the average over the last five years for the larger boats in the fleet. As we discuss below, we test the sensitivity of our model to the assumption that the herring fishery provides bait at cost by considering a scenario where the herring industry is able to charge a price equal to the cost of the substitute bait. This is presumably the maximum price they could charge if they were able to exercise market power, e.g., through formation of a cooperative.

\section{Economic Scenarios and Sensitivity Analysis}

The model is designed to investigate implications of the linkages between the herring and lobster fisheries for the sustainability and profitability of these fisheries. We defined scenarios with alternative assumptions about effort in the lobster fishery that provide insights into how changes in the management system of the fishery and resulting changes in effort would impact results (Table 1). We consider scenarios where lobster or herring recruitment declines to see how this affects the fishery system. We explore how results are affected if we assume lobster growth increases as a function of bait use as in Grabowski et al. (2010). We also consider the ramifications of higher bait prices that might occur if herring harvesters or bait dealers are able to exert market power and increase bait prices above cost. Finally we evaluate the sensitivity of the model to several model parameters that are uncertain.

\section{Lobster Effort Scenarios}


We simulate three contrasting lobster effort scenarios that are consistent with alternative assumptions about how effort and catch in the fishery is now, or could in future be, regulated. As described earlier, the base-case scenario fixes effort in the lobster fishery at historical (1998-2007) levels.

We then consider a scenario that assumes that the number of boats involved in the lobster fishery expands each year to the point where the economic profit ${ }^{5}$ of the fishery is driven to zero. We refer to this as the rent dissipation (RD) scenario. Although fishery rents would technically take into account changes in the value of the in-situ lobster stock, the concept of fishery rents as we use it here is synonymous with annual economic profit. Note that this scenario still allows the captain (owner) a positive income equal to the estimated opportunity cost of his labor but dissipates any profit beyond that. The lobster fishery is a highly seasonal fishery with most of the effort and catch occurring in late summer and fall. The rent dissipation scenario maintains the historical seasonal pattern of effort from the base case scenario but scales monthly fleet size up to the point where average annual economic profits are driven to zero (i.e., rents are dissipated).

The RD scenario is consistent with what should theoretically happen in a fishery if the regulatory system fails to constrain effort (Gordon 1954). However, an unofficial territorial system operates in some areas, particularly in areas adjacent to the coast and islands, and this may constrain effort below what might occur solely as a result of the regulatory and economic constraints in the fishery (Acheson 1988). Thus, our historical and RD scenarios likely bracket the present conditions in the fishery.

We then consider scenarios that assume maximization of the fishery's economic profit (MP) each year. Effort levels under profit maximization represent what we might expect to see if an ITQ system was implemented (Holland 2011) or perhaps very strict controls on licenses and trap limits that eliminate all latent effort. For this scenario the seasonal pattern (or profile) of effort from the base-case scenario is

\footnotetext{
${ }^{5}$ Economic profit is equal to the revenue less the opportunity cost of inputs. In this case that includes the opportunity cost (value) of the captain's time even though he might be receiving a direct wage.
} 
maintained but the optimization process adjusts the size of the fleet annually to maximize economic profit by varying the maximum number of boats involved in the fishery each year.

The "constant fleet" profit maximization scenario (MP.CF) investigates the consequences of spreading effort more evenly over the year. It maximizes profit subject to the constraint that the number of boats fishing (but not trap soak time) is the same every month. The fleet size is still adjusted annually to maximize annual profit. A constant monthly fleet size is closer to the monthly profile of fleet size that Holland (2011) showed maximized profit in the fishery. Note that this does not mean catch is even over the year since catch rates are still much lower in the winter.

\section{Recruitment, Growth and Bait Price Scenarios}

Both the herring and lobster fisheries have benefited from relatively high recruitment rates in recent years which may be the result of favorable environmental and ecological conditions that could change in future. We are interested in the robustness of the fisheries to failures in either herring or lobster recruitment; thus, we evaluate two scenarios featuring low recruitment for one species while base-case recruitment is maintained for the other species. Recruitment levels used in those scenarios are set to half the values used in the base case which are approximately equivalent to the lowest recruitment values for the last two decades for both herring and lobster.

Faster lobster growth of juvenile lobsters resulting from the large amounts of herring used as bait in the fishery have been proposed as a potential driver for the increasing catches over the last few decades (Grabowski et al. 2010). To test the ramifications of this hypothesis for our fishery system, we carry out a sensitivity analysis where growth is allowed to vary as a function of herring bait use. A functional relationship of type II between percentage increase in size (Growth), and the amount of bait used in traps in the 6 to 2 weeks preceding molt (bait) was derived with the form: 
(8) Growth $=\frac{a^{*} \text { bait }}{\left(1+b^{*} \text { bait }\right)}$

with $a=0.00297$ and $b=9.8 \mathrm{e}-05$ in summer and $a=0.00123$ and $b=3.99 \mathrm{e}-05$ in fall, and bait in metric tons.

The predicted increase in growth is implemented in the model by modifying the coefficients of the growth matrix for sublegal size lobsters in size bins 1 to 7 accordingly.

Our base model assumes that herring fishermen are price takers and sell their fish at a price that just covers harvest costs and therefore make no economic profit. We test the sensitivity of the model outcomes to this assumption by instead assuming the herring fleet is able to set the herring price such that the price of herring bait paid by lobstermen at all times is just equal to the price of the substitute bait. Thus the price received by herring fishermen is the substitute price of $\$ 0.30 / \mathrm{lb}$ less the $\$ 0.15 / \mathrm{lb}$ processor/dealer margin and the transport costs. The herring fleet is still assumed to operate to minimize harvest costs. They still harvest from the lowest cost areas to meet bait demand so the basic economic model for the fishery remains the same, but the quantity demanded for lobster bait under profit maximization or rent dissipation changes in response to the higher price. In addition, some profits accrue to the herring fishery. These recruitment, growth and herring pricing scenarios are run in conjunction with the rent dissipation and profit maximization scenarios for the lobster fishery.

\section{Sensitivity Analysis}

The sensitivity analysis is aimed at identifying the model assumptions that impact the results the most, and at testing the robustness of our conclusions to major uncertainties of the model. In combination with changes in the assumptions of lobstermen effort and bait effect on lobster growth, assumptions regarding herring management, catchability, and migration are modified (Table A10). 
Most important uncertainties relate to the herring model since the lobster population model is directly derived from the assessment model and the lobstermen economic model was extensively explored by Holland (2011). Herring migrations, and particularly the specific movements of each stock, are qualitatively understood through scientific surveys. This qualitative knowledge is used to allocate the TAC across management areas and serve as the basis of the model parameterization for migrations and management spatial scheme, which aims at releasing pressure on the Gulf of Maine stock. We investigate the efficiency of this protection and the consequences of uncertainty of the migration pattern by running the model using other migration rates and the spatial allocation of the TAC defined in 2002, before the revision of the TAC spatial allocation (the alternative management scenarios in Table A10).

For a schooling species, the relationship between CPUE and biomass is difficult to estimate, because CPUE may remain stable as the stock declines (hyperstability). The production functions estimated here clearly show hyperstability and thus cause the link between biomass and herring price to be weak except at very low biomass. Our confidence in the functional relationship between CPUE and biomass at low biomass levels is limited by a lack of observations of fishing at low biomass. Therefore we test the sensitivity of our model to a stronger link between biomass and CPUE whereby CPUE drops off at higher biomass levels than our originally estimated production function. 


\section{Results}

The base case scenario predicts biomass, catches, profits, and other outcomes assuming historical effort levels persist in the lobster fishery and the basic management framework of the two fisheries remains unchanged (Table 2). While these results may be of some interest in themselves, the value of the model is less in predicting absolute outcomes than in evaluating the relative changes in outcomes that result from changes in the way the fisheries are managed and prosecuted or from exogenous changes such as changes in recruitment. We first present how the different lobster effort scenarios affect outcomes before showing how these results are affected when recruitment to either fishery is reduced or if lobster growth is impacted by total bait use. Finally we present the results of the other sensitivity analyses.

\section{Results from Lobstermen Effort Scenarios}

The alternative effort scenarios have very little impact on lobster catch and gross revenue despite large differences in effort levels. Differences in annual catch attributable to effort scenarios (assuming base cases assumptions about recruitment and lobster growth) are less than $1 \%$.

Across the four scenarios with base-case recruitment and growth assumptions, maximum monthly fleet size varies between 807 and 3198 vessels compared to a maximum fleet size of 1650 in the historical effort scenario (Figure 3, Table 2). Rent dissipation results in the most boats operating, and profit maximization with a constant fleet size over the year results in the fewest boats. The rent dissipation scenarios result in fleet sizes that are considerably higher than the historical average, but the maximum monthly fleet size remain well below the number of authorized licenses in the current fishery.

Relative to the base-case historical effort scenario, total cost of labor, including crew payments and the total opportunity cost of the captains' time are slightly lower under profit maximization ( $5 \%$ less with a constant fleet) and $20 \%$ higher under rent dissipation. The increase in labor costs under rent dissipation is attributable solely to increased total opportunity cost of captains' time. The wages paid to crew, 
which are $20 \%$ of net revenue (gross revenue less fuel and bait costs), are actually lower under rent dissipation than under profit maximization and the effective wage per day for crew is much lower. Total crew payments are lower due to an increase in variable costs and a higher number of days fished without any increase in revenue that would reduce daily crew earnings.

Economic profit is $38 \%$ higher under profit maximization with a seasonal fleet relative to historical effort and $44 \%$ higher with a constant fleet. Under profit maximization with a constant fleet the maximum number of boats in the fishery is reduced by $30 \%$ for about the same catch level (relative to profit maximization with the seasonally varying fleet), and profit and total wages increase by just under $4 \%$. In winter, prices drop by $15 \%$ compared with the seasonal fishery scenario (due to higher catches in winter), but they stay nearly the same in summer. Economic profits under rent dissipation are zero by assumption.

Economic profit is the net profit minus the opportunity cost of the captains' time; however, we might also be interested in the total income to the captain. This is the gross revenue less fuel, bait and crew share and is equal to the sum of economic profit and the total opportunity cost of captains time. Total income for the captains is still highest with profit maximization but the difference relative to the other scenarios is smaller (Table 2) since part of the decrease in profit is simply a shift of income from profit (accruing to the license) to opportunity cost of captain's time (i.e. captain's wages). However, the vessel owners work more days to achieve that income.

The changes in effort across scenarios only slightly increase the pressure on the lobster population and have varying impacts on biomass of the two herring stocks. Lobster biomass is $3 \%$ lower under rent dissipation relative to historical effort and $10 \%$ higher under profit maximization. The increase in effort and resulting bait use under rent dissipation has a much greater impact on Georges Bank herring biomass which declines by $57 \%$ relative to historical effort (Table 2, Figure 4). Georges Bank herring 
biomass under profit maximization increases by $8 \%$ assuming a seasonal fleet, but declines by $3 \%$ with a constant fleet. The pressure on Georges Bank herring under profit maximization with a constant fleet is higher due to the higher quantity of bait demanded in winter when herring cannot be harvested in area 1A. Surprisingly Gulf of Maine herring biomass actually increases under both rent dissipation and profit maximization (Table 2, Figure 4). This results from the dependence of the TAC on the total biomass. In the historic scenario the quantity of bait demanded is not very high and can be satisfied by fishing herring in area $1 \mathrm{~A}$ mainly. Fishing pressure on Georges Bank herring being low, the global herring biomass stays high and so does the TAC, allowing a large part of herring to be caught in 1A. The extra quantity of bait demanded in the RD scenario causes herring catch to increase but the increase is absorbed by the Georges Bank stock in areas 2 and 3. Substitute baits represent about $20 \%$ of bait in the RD scenarios while no substitute bait is needed in the MP scenarios.

\section{Recruitment, Growth, and Bait Price Scenarios:}

The reduced herring recruitment scenario had almost no impact on the lobster fishery (Table 3, Figure 3). Neither catch, fleet size, profits nor labor costs changed by more than $2 \%$ relative to the results with the same fishing behavior scenario (e.g. profit maximization or rent dissipation) and the base herring recruitment. This is mainly due to the relatively small increase in bait prices caused by the drop in recruitment (up to $\$ 0.05 / \mathrm{lb}$ ). The small increase in herring price results from the displacement of effort on Georges Bank earlier in the year due to a more limiting TAC. Even with higher prices and a lower TAC, herring catch still satisfies the demand for bait in the MP scenarios. In the RD scenario however, $56 \%$ of bait must be provided by the substitute bait. The need for alternate bait arises because the TAC becomes limiting, not because of a rise in herring prices, which stay below the substitute price. Herring prices do not rise to the substitute prices because CPUE is not greatly affected by the decline in herring biomass so harvest costs do not rise. The increased bait costs reduce crew share, resulting in slightly lower labor costs in the lobster fishery. 
Lower herring recruitment does result in much lower herring biomass for both the Georges Bank and Gulf of Maine stocks but the relative impacts on the two herring stocks depend on the effort scenario (Table 3, Figure 4). The relative decline in Georges Bank herring biomass (68\%) is actually greater under profit maximization than rent dissipation (56\%) though the absolute biomass for Georges Bank herring under profit maximization with low recruitment is nearly double that under rent dissipation.

As expected, a drop in lobster recruitment impacts the lobster fishery. More surprisingly, reducing lobster recruitment also impacts the herring stocks (Table 3, Figures 3\&4). The drop in lobster recruitment results in a 50\% decrease in lobster catch for both rent dissipation and profit maximization and in $44 \%$ and $49 \%$ decreases in maximum lobster fleet size respectively under rent dissipation and profit maximization. Labor costs (crew and captains wages) decline by $44 \%$ and $46 \%$ respectively. Economic profit, under profit maximization, declines by $44 \%$. The reduction in the lobster fleet reduces the quantity of bait demanded but the impacts on the two herring stocks differ. Under profit maximization the reduction in lobster recruitment results in $1 \%$ increase in Georges Bank herring biomass and a $24 \%$ increase in Gulf of Maine herring biomass. Under rent dissipation with reduced lobster recruitment, Georges Bank herring biomass more than doubles, but Gulf of Maine biomass is actually reduced by $9 \%$. These somewhat paradoxical results again relate to the fact that an increase in the overall herring biomass increases the TACs allowing a greater proportion of the catch to be taken from the Gulf of Maine stock in area 1A which allows Gulf of Maine herring catch under lobster rent dissipation to increase.

Adding an effect of bait on growth impacts the lobster industry, supporting higher catches, a larger fleet, and higher payments to labor (Table 3, Figure 3). Under profit maximization, profit is also higher when the growth effect of bait is included. The relative increase in lobster catch due to the bait effect on growth is greater under rent dissipation (29\%) than under profit maximization (17\%), and the relative 
increase in labor costs is also greater (Table 3). The increase in lobster productivity directly benefits the fishery through a higher biomass of legal-size lobster. Paradoxically, overall lobster biomass is lower (especially in the rent dissipation scenario) in those simulations because small lobsters, which usually represent $50 \%$ of the biomass, reach minimum legal size faster. The impact on herring stocks is small despite an increase in the quantity of bait demanded of about $25 \%$. The biggest impacts are on Gulf of Maine herring biomass, which declines by $11 \%$ under profit maximization.

Relaxing the assumption that the herring fishery is a price-taker does not change the outcomes for the lobster industry which again appears very robust. Fixing the price of herring at $\$ 0.30 / \mathrm{lb}$ leads to only small changes in the outputs $(<3 \%)$ compared to the references cases (Table 3). Larger differences appear in herring biomass and catches under the rent dissipation. The price of Georges Bank herring sometimes exceeded the substitute price in the scenarios where fishermen were price takers, causing substitute to be used instead of herring. In the present scenario, the price of Georges Bank herring can never exceed the substitute price, and herring is always preferred. This causes an increase in harvested quantities and a reduction of herring biomass by $25 \%$ compared to the reference rent dissipation scenario. From the herring fishery's point of view however, the lobster fishery rent dissipation scenario allows higher revenues ( $60 \%$ increase compared to lobster profit maximization) but caused an increase in costs by $70 \%$.

\section{Sensitivity Analysis:}

The sensitivity analysis confirms that the performance and structure of the lobster industry mostly depends on lobstermen effort and on the hypotheses made on the effect of bait on lobster growth. The other parameters tested in the sensitivity analysis, which were related to uncertainties in the description of the herring fishery, have negligible impact on the lobster fishery (Table A10). Assumptions made in the herring model also have little impact on the Georges Bank herring stock. For the Georges 
Bank stock, small variations due to alternative migration and catch functions are only observed under the rent dissipation scenario. Effort in the lobster fishery is the main driver of biomass value for the Georges Bank stock (Figure 5). However, assumptions made in the herring model impact the biomass of the Gulf of Maine stock. The predicted values of biomass for this stock are particularly dependent on herring management schemes (Figure 5). Altering the assumptions regarding lobstermen effort and bait effect, leads to variations in biomass of up to $20 \%$. The other assumptions tested in the sensitivity analysis (alternative catch function and migration patterns) have relatively minor impact on Gulf of Maine stock biomass (1-7\% increase). The conclusions on the evolution of Gulf of Maine herring stock are thus uncertain and depend on management decisions and the effect bait has on lobster growth.

\section{Discussion}

Effort in the lobster fishery has continued to increase over the last decade, and the territorial system, which mainly operated in the areas close to coast and islands (Acheson 1988), may be less effective in open water areas to which the fishery has spread as it expanded. Thus, the current fishery is likely somewhere in between the historical effort scenario and the rent dissipation scenario. The assumption of zero economic profit is, however, consistent with recent studies. Thunberg (2007) estimated that average economic profits (after subtracting opportunity costs of labor and capital as well as out-ofpocket expenses) were negative in 2005 , though some vessels appeared to be operating at a profit. A detailed cost-earnings survey of 18 lobstering operations of varying sizes and locations also found negative economic profits on average but both profitable and unprofitable operations (Holland 2011b).

Our model shows that lobster fishery profits could be substantially increased by reducing effort levels, although total catches would be almost identical to those associated with historical or rent dissipating 
effort levels. Increases in economic profits result from savings on bait and fuel but also a reduction in labor costs (i.e. payments to crew). Total crew payments, which are a percentage of net revenues, are relatively unaffected by lobster effort levels since catch and revenues do not vary much. However, crew wage per day is much higher under profit maximization since the catch is harvested by fewer vessels and crew. The total opportunity cost of the captain's time (which is subtracted when calculating economic profit) is much lower under profit maximization, increasing economic profit but decreasing total labor costs if both actual crew payments and the value of the captain's time are included. The results of the profit maximization scenarios may overestimate increases in crew share and underestimate increases in profit since some of the increase in crew share is likely to be shifted to vessel owners by decreasing the percent of net revenues paid to crew. The higher crew wage per day would be expected to attract more crew labor to the fishery making it possible for captains to reduce crew share or find alternate crew willing to take a lower percentage.

The development of a winter lobster fishery and a more even distribution of effort over the year has been suggested as a potential way to improve fishery profitability by moving catch into winter when prices are higher and reducing catches in summer when prices are low (Cheng and Townsend 1993). However our results do not fully support this suggestion. Profit optimization implies a lower fleet size and some shifting of catch into winter, but catch remains heavily concentrated in the summer. Even though prices are higher in winter, the low catch rates in winter, and consequent higher costs of bait and fuel per unit of catch, limit gains from moving catch from summer to winter. The increase in profit under the profit maximization scenario comes primarily from reducing effort and costs rather than increasing prices. Shifting catch into winter also requires more bait for the same level of catch. This would increase pressure on the Georges Bank herring stock which must supply the bait for the winter fishery, assuming fresh herring is used for bait. If herring from area $1 \mathrm{~A}$ were frozen and held for use in 
the Winter, this might reduce pressure of the Georges Bank stock but it might also add substantial cost to the bait, and fishermen have generally preferred fresh bait if they can get it.

The model suggests that the lobster fishery is robust to declines in herring recruitment and limited changes in the spatial allocation of the herring TAC. This robustness is mainly due to the low correlation between herring biomass and herring prices. This correlation results from the weak relationship between herring biomass and CPUE and the assumption that herring fishermen are price takers and make no profit on herring. These assumptions appear reasonable under current management, first because we are not assuming here that these fleets make no profit at all, herring is not their only source of revenue -they usually fish mackerel part of the year; second, because the price of herring is not correlated with landings over the last period 1980-2005 (Thunberg, 2007). Furthermore, the conclusion on lobster industry robustness remains true, even if we allow for a stronger link between biomass and price by increasing the correlation between herring biomass and CPUE. Even if herring price is fixed at the substitute price, the lobster fishery is not greatly affected.

While our analysis suggests the lobster fishery is not substantially impacted by the herring fishery, the opposite is not true. Herring catches and stocks are heavily affected by changes in lobster management that impact lobster effort levels and the amount of bait needed. A two-fold increase in lobster fleet size could lead to a $60 \%$ decrease of the Georges Bank herring component and near collapse if it is combined with low recruitment. However, the risk to Georges Bank stock may be overstated if Georges Bank is actually less accessible than assumed in the model. For example, weather conditions and increasing fuel price might prevent fishermen from traveling to Georges Bank or may cause an increase in price possibly to the point where other baits (or freezing and holding herring from the fall fishery) become less costly. It is also likely that any decrease in the Georges Bank stock would be detected through the annual surveys and stock assessments and that appropriate management actions would be taken. The Gulf of 
Maine stock appears to be well protected by the current specifications of the TAC, at least better than with the previous management scheme and within the lobstermen-effort scenarios we explored.

Paradoxically, the coastal herring component would be more threatened in situations where the quantity of bait demanded by the lobster fishery is lower. When the quantity of bait demanded is moderate most of the demand can be satisfied with catches from area $1 \mathrm{~A}$, the preferred herring-fishing area. Because the TAC is set based on the combination of both the Gulf of Maine and Georges Bank stocks, the reduction in the Gulf of Maine stock is offset by a high Georges Bank stock biomass allowing the overall herring TAC to remain high. Allocation of a higher proportion of the TAC to area $1 A$, as done prior to 2010, would only affect the stock in the case of an increased need for bait (scenarios with growth subsidy and rent dissipation). Distinguishing between the two stocks during the assessment process would help ameliorate this effect if it allowed for setting of area-specific TACs that reflected the biomass of the two stocks rather than the combined biomass.

The reasons for the growth of lobster catches under such continuously high fishing pressure, and potential vulnerability of the fishery to reductions in recruitment or growth remain open questions. The findings of Grabowski et al. (2010) on the effect of herring bait on lobster growth provide at least a partial explanation for the high productivity of the lobster fishery, creating a positive feedback between fishing and growth. Our model suggests this growth subsidy from herring bait could indeed have a significant positive impact on long-run catch. However, faster growth does not necessarily result in higher overall lobster biomass. While legal-size biomass increases, overall biomass may actually decrease due to lobsters growing to legal size more quickly. Some caveats are in order when considering the modeled effect of herring bait on the lobster growth. The modeled relationship is based on only two years of data, and the functional shape of the relationship must be assumed. Experiments carried out in Canada tend to support a logistic shape for this effect (Grabowski et al. 2009) but the data 
at hand did not allow us to assess the parameters of such a relationship. We also assumed that other baits, not only herring, would provide that positive effect. It seems reasonable that menhaden (Brevoortia tyrannus) would have a similar growth effect to herring, but other alternative baits such as fish racks (heads and other discarded parts from processed fish) might have less impact on growth. In any case, use of substitute baits was fairly limited in the scenarios for which we modeled the growth effect. The reasons for the robust lobster population more likely lie in the other causes discussed in the introduction including the reduction in predators and favorable environmental conditions.

Our model also shows that changes in market power of herring harvesters that would allow them to charge higher prices would have limited impacts. Assuming the herring fishery is able to charge a price of $\$ 0.30 / \mathrm{lb}$, the substitute price in our model, as might be the case if, for example, the herring fleet operated as a cooperative, we expected to see a transfer of some lobster profits to the herring fishery. However, the scale of the transfer was limited since the price assumed for the substitute bait was still low. If substitute bait costs were higher or sensitive to the quantity demanded, potential transfers of profits to the herring fishery could be greater.

The sensitivity analysis suggests that our results are robust to the assumptions made in the model. We varied the most uncertain parameters, notably, the functional relationships and parameters that were not derived from assessment models or from previously published works. Except for management and lobsterman fishing strategies, the most influential factor was the effect of bait on lobster growth. Further research on the influence of bait on lobster growth is clearly warranted. The sensitivity analysis also provides useful information regarding the management of the fisheries. It showed that the Georges Bank herring stock is simpler to manage due to a more predictable response to management actions than the Gulf of Maine stock. Georges Bank herring biomass is only sensitive to controllable features of the fishery (lobster fishery effort and herring TAC) which can be adjusted by management choices 
(though not necessarily choices controlled by managers of the herring fishery). On the other hand, the predictions of the biomass of the Gulf of Maine stock are less clear because they are affected by processes that are uncertain, particularly the effect of bait on lobster growth (Figure 5). Consequently it is less clear what management actions are needed to reduce risk for the Gulf of Maine herring stock. On a positive note, current management of the herring fishery seems to be the most precautionary regarding uncertainties and regardless of the choices made in the lobster fishery. In addition, over all the scenarios investigated, herring biomass varied less than 20 percent.

The model demonstrated the importance of taking into account the impacts that the lobster and herring fisheries have on each other when evaluating management measures. Coordinated management has increasingly been advocated, but the conditions in which it would be beneficial are often not clear (White et al. 2012). While our work does not explicitly investigate the benefits of joint management, it points out changes that could benefit both fisheries, but also illustrates trade-offs within and between fisheries. Reducing lobster effort reduces pressure on herring and increases herring biomass while increasing profit in the lobster fishery. However this would reduce revenues in the herring fishery. The model suggests that reducing TACs for herring in the Western Gulf of Maine would have only a limited impact on the lobster fishery but might increase risk for the Georges Bank herring stock. Effective joint management would require the identification of clear ecological and economic objectives and an understanding of how the quantity of bait demanded by the lobster fishery under alternative management arrangements (e.g. quotas or effort controls) would affect the amount and spatial distribution of herring catch given a particular formula for setting the herring TAC and distributing it across areas.

There is increasing recognition of the need to account for connections between fisheries, and for the development of an ecosystem approach to managing fisheries, making the question of the best 
modeling approach topical (Espinoza-Tenorio et al. 2012). Ecosystem models such as Ecopath with Ecosim (Christensen and Walters 2004) or Atlantis (Fulton 2004; Fulton et al. 2011) have been proposed as a mechanism to encompass the entire knowledge of a system, usually with emphasis on trophic relationships. Several of these "end-to-end" models, some linked with economic frameworks, have been developed for the Gulf of Maine- Georges Bank region (Jin et al. 2012; Collie et al. 2009; Link et al. 2008; Steele et al. 2007). While ecosystem models are useful in developing a qualitative understanding of the overall ecosystem, they might not always be appropriate to inform management decisions because of gaps in information, uncertainty about system dynamics, computational constraints, the lack of explicit modeling of economic and regulatory processes, and the incompatibility of scales or assumptions with the single-species assessment models currently integrated into fisheries management (Rose et al. 2010). This often leads to difficulties in applying the results to support management decisions (see for instance Jin et al. 2012). While several authors provided guidance for the careful reporting and management of these uncertainties and sensitivities (see for instance Link et al. 2012; Punt and Donovan 2007), validation is still rarely carried out for such complex models because all available information is already used for parameterization (Lehuta et al. 2013). Validation against future changes in the system is a critical step to build confidence in these more complex models. Sensitivity analysis is even more critical to evaluate the robustness of results and also identify the parameters and processes for which information is most needed to reduce model uncertainty.

As a trade-off between the consideration of linkages within an ecosystem and the limitation of complexity, we adopted an approach that combines existing information, individually validated models, and empirical analyses, to build a coupled model of the lobster fishery in Maine and Northeast US herring fishery. Each module makes use of parameters and data also employed in assessment models, and is defined at an appropriate scale that matches the scale of the assessment model or the scale at which regulation is implemented. This increases the transparency and credibility of the model and 
transferability of its results to management decisions. As a consequence, the full model structure is relatively simple (at least in comparison to an end-to-end ecosystem model), and the complexity arises from the dynamic interactions between the modules.

As our understanding of ecosystem dynamics and computing power increases, our ability to model the more complex ecosystem holistically will no doubt increase. But at present the intermediate approach of linking single species models provides a means to begin to evaluate trade-offs inherent in ecosystembased management, and eventually, to operationalize an ecosystem-based approach.

\section{Acknowledgements}

This work was founded by National Science Foundation, Coupled Natural and Human Systems Program, Award\# 0709527. The authors wish to thank Yong Chen and Jui-Han Chang (University of Maine) who helped in the development and programming for the lobster model, Jonathan Deroba (NOAA) and Matthew Cieri (Maine DMR) who provided data on the herring fishery and helped shape the herring model, Jonathan Grabowski (Marine Science Center, Northeastern University) who provided guidance for the modeling of bait effect on lobster growth, and Min-Yang Lee (NOAA) who provided data on herring harvest costs. The authors also thank three anonymous reviewers and the associate editor for valued comments that improved the manuscript.

\section{References}

Acheson, J.M. 1988. Lobster Gangs of Maine. University Press of New England, Hanover, NH.

Atlantic States Marine Fisheries Commission (ASMFC). 2009. American lobster stock assessment report for peer review. Stock Assessment Report No. 09-01 (Supplement).Atlantic States Marine Fisheries Commission, Washington, DC. 366 pp.

Brandt, S. and McEvoy, D. 2006. Distributional effects of property rights: Transitions in the Atlantic Herring fishery. Mar. Policy 30(6): 659-670.

Brown, G., Berger, B. and Ikiara, M. 2005. A predator-prey model with an application to Lake Victoria fisheries. Marine Resource Economics 20(3):221-248. 
Chen, Y. and Wilson, C. 2005. Developing and evaluating a size-structured stock assessment model for the American lobster, Homarus americanus, fishery. N. Z. J. Mar. Freshwater Res. 39: 645-660.

Cheng, H.T. and Townsend, R.E. 1993. Potential impact of seasonal closures in the US lobster fishery. Marine Resource Economics 8(2): 101-119.

Christensen, V., and Walters, C.J. 2004. Ecopath with Ecosim: methods, capabilities and limitations. Ecol. Modell. 172: 109-139.

Collie, J.S., Gifford, D.J. and Steele, J.H. 2009. End-to-end foodweb control of fish production on georges bank. ICES J. Mar. Sci. 66: 2223-2232.

Deroba, J.J. 2010. An updated spatial pattern analysis for the Gulf of Maine-Georges Bank Atlantic herring complex during 1963-2009. US Dept Commer, Northeast Fish Sci Cent Ref Doc. 10-18; 18 p. Available from: National Marine Fisheries Service, 166 Water Street, Woods Hole, MA 02543-1026, or online at http://www.nefsc.noaa.gov/nefsc/publications/.

Drinkwater, K.F., Harding, G.C., Mann, K.H. and Tanner, N. 1996. Temperature as a possible factor in the increased abundance of American lobster, Homarus americanus, during the 1980s and early 1990s. Fish. Oceanogr. 5: 176-193.

Driscoll, J. 2008. A life cycle assessment of the Maine lobster industry. Master's thesis, Dalhousie University School for Resource and Environmental Studies, Halifax.

Espinoza-Tenorio, A., Wolff, M., Taylor, M.H. and Espejel, I. 2012. What model suits ecosystem-based fisheries management? A plea for a structured modeling process. Rev. Fish Biol. Fish. 22: 81-94.

Flaaten, O. 1989. The economics of predator-prey harvesting. In: P.A. Neher, R. Arnason and N. Mollett (eds.), Rights Based Fishing. Kluwer Academic Publ., Nordrecht, 485-503.

Fogarty, M. and Gendron, L. 2004. Biological reference points for American lobster (Homarus americanus) populations: limits to exploitation and the precautionary approach. Can. J. Fish. Aquat. Sci. 61: 1392-1403.

Fulton, E.A. 2004. Biogeochemical marine ecosystem models II: the effect of physiological detail on model performance. Ecol. Modell. 173: 371-406. doi: 10.1016/j.ecolmodel.2003.09.024.

Fulton, E.A., Link, J.S., Kaplan, I.C., Savina-Rolland, M., Johnson, P., Ainsworth, C., Horne, P., Gorton, R., Gamble, R.J., Smith, A.D.M. and Smith, D.C. 2011. Lessons in modelling and management of marine ecosystems: the Atlantis experience. Fish Fish. 12: 171-188. doi: 10.1111/j.1467-2979.2011.00412.x. 
Gordon, H. Scott. 1954. The Economic Theory of a Common-Property Resource: The Fishery. Journal of Political Economy 62:124-142.

Grabowski, J. H., Clesceri, E. J., Baukus, A. J., Gaudette, J., Weber, M. and Yund, P. O. 2010. Use of herring bait to farm lobsters in the gulf of Maine. PLoS ONE 5 (4): e10188.

Grabowski, J.H., Gaudette, J., Clesceri, E.J. and Yund, P.O. 2009. The role of food limitation in lobster population dynamics in coastal maine, united states, and new brunswick, canada. N. Z. J. Mar. Freshwater Res. 43: 185-193.

Hannesson, R. 1983. Optimal harvesting of ecologically interdependent species. J. Environ. Econ. Manag. 10: 329345.

Hilborn, R. and Walters, C. 1992. Quantitative fisheries stock assessment: choice, dynamics and uncertainty. Chapman and Hall, New York.

Holland, D.S. 2011. Optimal Intra-annual Exploitation of the Maine Lobster Fishery. Land Econ. 87(4):699-711.

Holland, D.S. 2011b. Understanding the Econmic Structure of the Gulf of Maine Lobster Industry. Final Project Report for Cooperative Institute for the North Atlantic Region (CINAR) Grant No.

NA09OAR4320129, Subaward A100730.

Incze, L.S., Wahle, R.A., Wolff, N., Wilson, C., Steneck, R., Annis, E., Lawton, P., Xue, H., Chen, Y. 2006. Early life history of lobster (Homarus americanus) populations in the Gulf of Maine. J. Crustacean Biol. 26: 555564.

Jin, D., Hoagland, P., Dalton, T.M. and Thunberg, E.M. 2012. Development of an integrated economic and ecological framework for ecosystem-based fisheries management in New England. Prog. Oceanogr. 102: 93-101.

Jury, S.H., Howell, H., O'Grady, D.F. and Watson, W.H. 2001. Lobster trap video: in situ video surveillance of the behaviour of Homarus americanus in and around traps. Mar. Freshwater Res. 52:1125-1132.

Lehuta, S., Petitgas, P., Mahévas, S., Huret, M., Vermard, Y.et al 2013. Selection and validation of a complex fishery model using an uncertainty hierarchy. Fish. Res. 143: 57-66.

Link, J.S., Ihde, T.F., Harvey, C.J., Gaichas, S.K., Field, J.C.et al 2012. Dealing with uncertainty in ecosystem models: the paradox of use for living marine resource management. Prog. Oceanogr. 102: 102-114. 
Link, J., Overholtz, W., O'Reilly, J., Green, J., Dow, D. et al. 2008. The northeast US continental shelf energy modeling and analysis exercise (emax): ecological network model development and basic ecosystem metrics. J. Marine Syst. 74: 453-474.

Maine Department of Marine Resources (MDMR) 2013. Available at: http://www.maine.gov/dmr/commercialfishing/

McMahan, M.D., Brady, D.C., Cowan, D.F., Grabowski, J.H., and Sherwood, G.D. 2013. Using Acoustic Telemetry to Observe the Effects of a Groundfish Predator (Alantic Cod, Gadus Morhua) on Movement of the American Lobster (Homarus Americanus). Can. J. Fish. Aquat. Sci. In Press.

Mills, K. E., Pershing, A. J., Brown, C. J., Chen, Y., Chiang, F., Holland, D. S., Lehuta, S., Nye, J. A., Sun, J. C., Thomas, A., Wahle, R. A. 2013. Fisheries management in a changing climate: lessons from the 2012 ocean heat wave. Oceanography, 26.

National Marine Fisheries Service. 2008. Results of 2006/2007 Northeast Fishing Vessel Annual Cost Survey. Available at https://fish.nefsc.noaa.gov/fvcs.

National Marine Fisheries Service (NMFS). 2013. Available at: http://www.st.nmfs.noaa.gov/st1/commercial/landings/annual_landings.html.

New England Fishery Management Council (NEFMC). 2010. Proposed Atlantic herring specifications for the 20102012 fishing years. New England Management Council. Available at: http://www.nero.noaa.gov/nero/regs/frdoc/10/10Herring2010SpecsEA.pdf.

Northeast Fisheries Science Center (NFSC). 2012. 54th Northeast Regional Stock Assessment Workshop (54th SAW) Assessment Summary Report. US Dept Commerce, Northeast Fish. Sci. Cent. Ref. Doc. 12-14; 40 p. Available at http://www.nefsc.noaa.gov/nefsc/publications/.

Overholtz, W.J., Jacobson, L.D., Melvin, G.D., Cieri, M., Power, M., Libby, D., Clark, K. 2004. Stock assessment of the Gulf of Maine - Georges Bank Atlantic herring complex, 2003. Northeast Fish. Sci. Cent. Ref. Doc. 04-06; 290 p. Available from: National Marine Fisheries Service, 166 Water St., Woods Hole, MA 02543.

Overholtz, W.J., Link, J.S. 2007. Consumption impacts by marine mammals, fish, and seabirds on the Gulf of MaineGeorges Bank Atlantic herring (Clupea harengus) complex during the years 1977-2002. ICES Journal of Marine Science 64:83-96. 
Paulik, G. J., A. S. Hourston, and P. A. Larkin. 1967. Exploitation of multiple stocks by a common fishery. Journal of the Fisheries Research Board of Canada 24:2527-2537.

Pearce, J and Balcom, N. 2005. The 1999 Long Island Sound Lobster mortality event: Findings of the Comprehensive Research Initiative. J. Shellfish Res. 24:691-697.

Pershing, A.J., Wahle, R.A., Meyers, P.C., Lawton, P. 2012. Large-scale coherence in New England lobster (Homarus americanus), settlement and associations with regional atmospheric conditions. Fish. Ocean. 21:348-362.

Punt, A.E. and Donovan, G.P. 2007. Developing management procedures that are robust to uncertainty: lessons from the international whaling commission. ICES Journal of Marine Science 64: 603-612.

Ricker, W.E. 1958. Maximum sustained yields from fluctuating environments and mixed stocks. Journal of the Fisheries Research Board of Canada 15:991-1006.

Rose, K., Allen, J.I., Artioli, Y., Barange, M., Blackford, J. et al. 2010. End-To-End Models for the Analysis of Marine Ecosystems: Challenges, Issues, and Next Steps. Marine \& Coastal Fisheries 2: 115-130. doi: 10.1577/C09-059.1.

Ryan, R.W., Holland, D.S. and Herrera, G. 2010. Bioeconomic Equilibrium in a Bait-Constrained Fishery. Marine Resource Economics. 25(3):281-294.

Saila, S.B., Nixon, S.W. and Oviatt, C.A. 2002. Does lobster trap bait influence the Maine inshore trap fishery? North American Journal of Fisheries Management 22(2):602-605.

Shepherd, G., Cieri, M., Power, M. and Overholtz, W. 2009. Transboundary Resources Assessment Committee Gulf of Maine/Georges Bank Atlantic Herring Stock Assessment Update. TRAC reference document 2009/04. Available at: http://www.mar.dfo-mpo.gc.ca/science/trac/rd.html.

Steele, J.H., Collie, J.S., Bisagni, J.J., Gifford, D.J., Fogarty, M.J. et al. 2007. Balancing end-to-end budgets of the Georges bank ecosystem. Prog. Oceanogr. 74: 423-448.

Steneck, R.S. and Wilson, C.J. 200. Large-scale and long-term, spatial and temporal patterns in demography and landings of the American lobster, Homarus americanus, in Maine. Mar. Freshwater Res. 52: 1303-1319.

Thunberg, E.M. 2007. Demographic and economic trends in the Northeastern United States lobster (Homarus americanus) fishery, 1970-2005. U.S. Department of Commerce, Northeast Fish. Sci. Cent. Ref. Doc. 07$17 ; 64 \mathrm{p}$. 
Wahle, R.A., Gibson, M., Fogarty. M.J. 2009. Distinguishing disease impacts from larval supply effects in a lobster fishery collapse. Mar. Ecol. Prog. Ser. 376: 185-192. doi: 10.3354/meps07803

Wahle, R.A., Incze, L.S., Fogarty, M.J., 2004. First projections of American lobster fishery recruitment using a settlement index and variable growth. Bull. Mar. Sci. 74: 101-114.

White, C., Costello, C., Kendall, B.E. and Brown, C.J. 2012. The value of coordinated management of interacting ecosystem services. Ecol. Lett. 15: 509-519.

Zhang, Y., Li, Y. and Chen, Y. 2012. Modeling the dynamics of ecosystem for the American lobster in the gulf of Maine. Aquatic Ecol. 46: 451-464. 
Table 1: Simulation scenarios. The base case scenario recalls the basic assumptions of the base case. The other lines describe the changes made in each scenario. Abbreviations in parentheses correspond to those used in Figures 3 to 5.

\begin{tabular}{|c|c|}
\hline \multicolumn{2}{|r|}{ Base Case Scenario } \\
\hline & Basic assumptions \\
\hline Historical lobster effort & monthly fleet size set at $1998-2007$ average \\
\hline Cost minimizing herring fishery & herring ex-vessel price equals harvest cost including fixed costs \\
\hline Historical lobster recruitment & equal to average recruitment $1987-2007$ \\
\hline Historical herring recruitment & equal to average recruitment $1989-2008$ \\
\hline No bait effect on lobster growth & Lobster growth matrix from assessment \\
\hline \multicolumn{2}{|r|}{ Lobster Effort Scenarios } \\
\hline Scenario & Changes to base case scenario \\
\hline Rent dissipation (RD) & scale vector of monthly fleet size annually to dissipate all economic profits \\
\hline $\begin{array}{l}\text { Profit maximization - seasonal fleet } \\
\text { (MP) }\end{array}$ & scale vector of monthly fleet size to maximize profit \\
\hline $\begin{array}{l}\text { Profit maximization - Constant Fleet } \\
\text { (MP.CF) }\end{array}$ & fleet size constant across months adjusted annually to maximize profit \\
\hline \multicolumn{2}{|r|}{ Recruitment, Growth and Bait Price Scenarios } \\
\hline Scenario & Changes to Rent dissipation and Profit maximization scenarios \\
\hline Low herring recruitment (Rher) & Herring recruitment set equal to half $1988-2008$ average \\
\hline Low lobster recruitment (Rlob) & Lobster recruitment set equal to half the average of last 20 years \\
\hline Lobster growth (gro) & Growth matrix for sublegal lobster made function of bait use \\
\hline Herring pricing (Pher) & Bait price fixed at substitute price \\
\hline \multicolumn{2}{|r|}{ Sensitivity Analysis } \\
\hline Scenario & $\begin{array}{l}\text { Changes to Rent dissipation, Profit maximization and Lobster growth } \\
\text { scenarios }\end{array}$ \\
\hline Herring migration & Alternative migration rates assume (see Table A5) \\
\hline $\begin{array}{l}\text { Herring management } \\
\text { (cur.mgt/prev.mgt) }\end{array}$ & Allocation of TAC to areas based on method used prior to 2002 \\
\hline Herring CPUE & Alternative herring CPUE function that declines at higher biomass levels \\
\hline
\end{tabular}


Table 2: Results of the effort scenarios on the ten output variables. Actual numbers are shown for the Base case scenario (Historical) and for the variable "Substitute bait" for all scenarios. The results of the other scenarios are expressed as a percentage difference relative to the historical effort scenario. All results reflect values for the final year of the simulation (year 20).

\begin{tabular}{lrrrr}
\hline Output variables & Base Case & $\begin{array}{c}\text { Profit maximization } \\
\text { (MP) \% }\end{array}$ & $\begin{array}{c}\text { Profit maximisation - } \\
\text { constant fleet } \\
\text { (MP.CF) \% }\end{array}$ & $\begin{array}{c}\text { Rent dissipation } \\
\text { (RD) \% }\end{array}$ \\
\hline Lobster catch (mt) & 30141 & 1 & 0 & 0 \\
Lobster profit (k\$) & 132138 & 38 & 44 & -100 \\
Crew wages per day (\$) & 261 & 60 & 38 & -60 \\
Captain opportunity costs (k\$) & 31832 & -31 & -20 & 94 \\
Fleet size & 1651 & -31 & -51 & 94 \\
Lobster biomass (mt) & 77553 & 10 & 9 & -3 \\
Herring biomass GoM (mt) & 465574 & 18 & 20 & 15 \\
Herring biomass GB (mt) & 570189 & 8 & -3 & -57 \\
Herring catch (mt) & 58367 & -31 & -18 & 58 \\
Substitute bait (mt) & 0 & 0 & 0 & 20751 \\
\hline
\end{tabular}


Table 3: Results of the recruitment, growth and herring price scenarios on the ten output variables under profit maximization and rent dissipation. Actual numbers are shown for the scenarios of profit maximization and rent dissipation with base case recruitments, growth and herring price assumptions. The results of the other scenarios are expressed in term of relative difference in comparison to these two scenarios. All results reflect values for the final year of the simulation (year 20).

\begin{tabular}{|c|c|c|c|c|c|}
\hline Output variables & Base case & $\begin{array}{c}\text { Low herring } \\
\text { recruitment } \\
\text { (Rher) \% }\end{array}$ & $\begin{array}{c}\text { Low lobster } \\
\text { recruitment } \\
\text { (Rlob) } \%\end{array}$ & $\begin{array}{c}\text { Bait effect } \\
\text { on growth } \\
\text { (gro) } \% \\
\end{array}$ & $\begin{array}{c}\text { Herring } \\
\text { price (Pher) } \\
\% \\
\end{array}$ \\
\hline & \multicolumn{5}{|c|}{ Profit maximisation (MP) } \\
\hline Lobster catch (mt) & 30393 & 0 & -49 & 17 & 0 \\
\hline Lobster profit (k\$) & 182628 & 0 & -44 & 10 & -2 \\
\hline Crew wages per day (\$) & 418 & 0 & 8 & -9 & -1 \\
\hline Captain opportunity costs ( $\mathrm{k} \$$ ) & 21909 & -1 & -49 & 24 & -1 \\
\hline Fleet size & 1136 & -1 & -49 & 24 & -1 \\
\hline Lobster biomass (mt) & 85104 & 0 & -46 & -13 & 1 \\
\hline Herring biomass GoM (mt) & 551411 & -53 & 24 & -11 & 1 \\
\hline Herring biomass GB (mt) & 618134 & -68 & 1 & -2 & 0 \\
\hline Herring catch (mt) & 40173 & -1 & -49 & 24 & -1 \\
\hline Herring revenues ( $k \$$ ) & 5816 & 25 & -50 & 25 & 109 \\
\hline \multirow[t]{2}{*}{ Substitute $(\mathrm{mt})$} & 0 & 0 & 0 & 0 & 0 \\
\hline & \multicolumn{5}{|c|}{ Rent dissipation (RD) } \\
\hline Lobster catch (mt) & 30118 & 0 & -49 & 29 & 0 \\
\hline Lobster profit (k\$) & 0 & 0 & 0 & 0 & 0 \\
\hline Crew wages per day (\$) & 106 & 0 & 0 & 0 & 0 \\
\hline Captain opportunity costs ( $k \$$ ) & 61667 & -2 & -44 & 27 & -3 \\
\hline Fleet size & 3198 & -2 & -44 & 27 & -3 \\
\hline Lobster biomass (mt) & 75128 & 0 & -48 & -25 & 0 \\
\hline Herring biomass GoM (mt) & 536915 & -51 & -9 & -1 & 2 \\
\hline Herring biomass GB (mt) & 245166 & -56 & 106 & -4 & -25 \\
\hline Herring catch (mt) & 92323 & -47 & -31 & 3 & 7 \\
\hline Herring revenues $(\mathrm{k} \$$ ) & 16881 & -42 & -41 & 3 & 75 \\
\hline Substitute (mt) & 20751 & 200 & -100 & 135 & -100 \\
\hline
\end{tabular}


Figure Captions

Figure 1: Graphical representation of the model depicting the main components (modules) and interactions between them as well as control variables and objective functions for each. Pop stands for population.

Figure 2: Map of the study area with indication of herring management areas.

Figure 3: Results of the scenarios on the output variables relating to the lobster fishery expressed as variation in outcomes relative to the historical scenario. a) lobster catch; b) economic profit in the lobster fishery; c) maximum number of boats involved in the fishery; d) lobster biomass; e) total wages of crews; $f$ ) total opportunity costs of time of captains. The five columns on the left-hand side of each graph represents scenarios with maximization of profit (MP) and the columns on the right-hand side show results for rent dissipation (RD) scenarios. MP and RD are combined with other varying assumptions: "SF": seasonally varying fleet; "CF": constant number of boats over year; "Rher": low herring recruitment; "Rlob": low lobster recruitment; "gro": effect of bait on lobster growth; "Pher": herring price equal to substitute price.

Figure 4: Results of the scenarios on the output variables relating to the herring fishery expressed as variation in outcomes relative to the historical scenario for a) Gulf of Maine herring biomass, b) Georges Bank herring biomass, c) total herring catch; and in absolute numbers for d) the amount of herring and substitute bait used in the traps. The five columns on the left-hand side of each graph represents scenarios with maximization of profit (MP) and the columns on the right-hand side show results for rent dissipation (RD) scenarios. MP and RD are combined with other varying assumptions: "SF": seasonally varying fleet; "CF": constant number of boats over year; "Rher": low herring recruitment; "Rlob": low lobster recruitment; "gro": effect of bait on lobster growth; "Pher": herring price equal to substitute price.

Figure 5: Boxplot of the values obtained in the sensitivity analysis for the biomass of Gulf of Maine and Georges Bank herring stocks. The graph focuses on changes induced by the hypotheses on the management context. "MP-cur.mgt": profit maximization in the lobster fishery and current spatial management scheme for the herring fishery; "MP-prev.mgt.": profit maximization in the lobster fishery and previous spatial management scheme for the herring fishery,"RD-cur.mgt.": rent dissipation in the lobster fishery and current spatial management scheme for the herring fishery; "RD-prev.mgt.": rent dissipation in the lobster fishery and previous spatial management scheme for the herring fishery. The black dots indicate the value in the base case scenario for reference (no bait effect on growth, base case herring migration and catchability). 


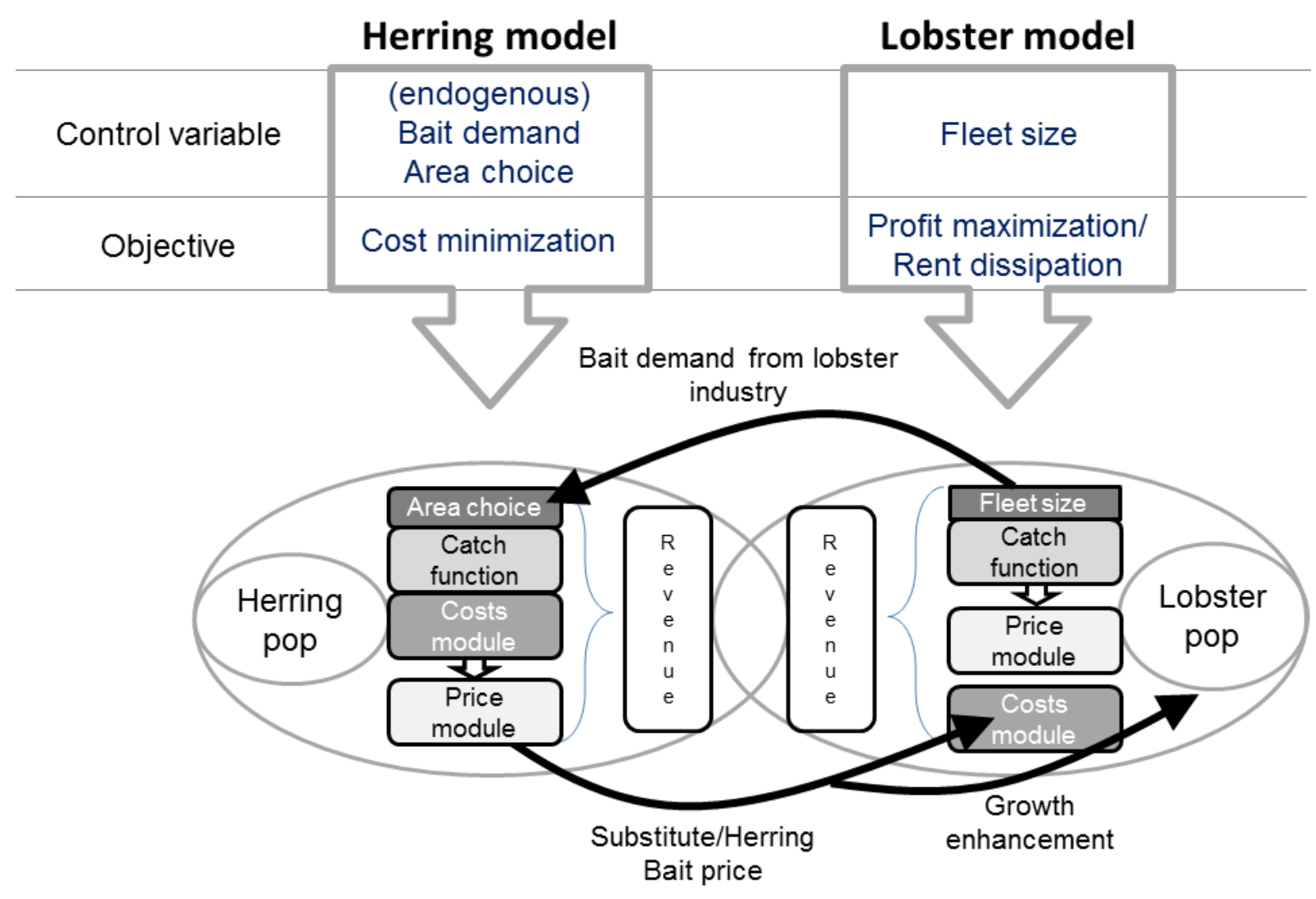

Figure 1 


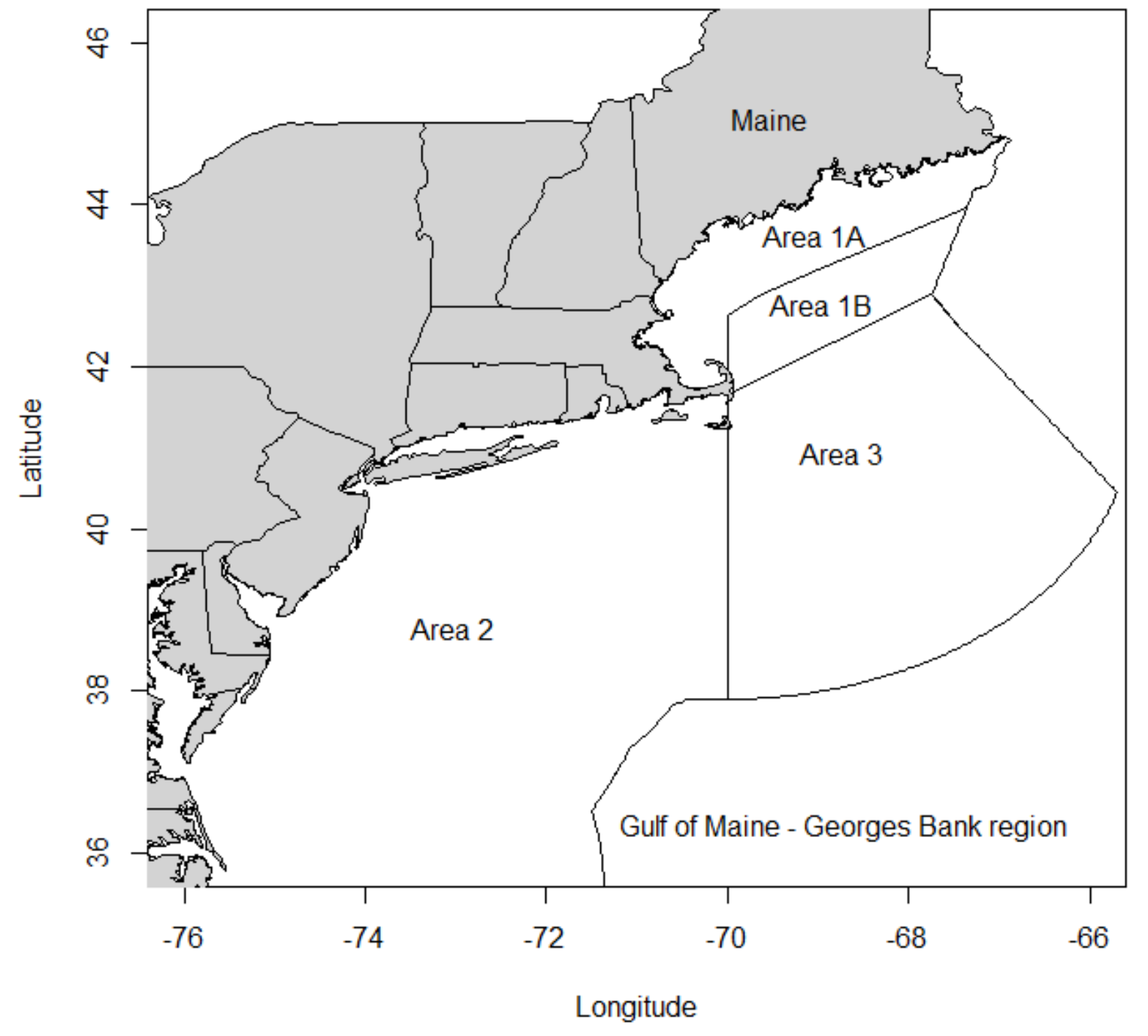

Figure 2 
a) Lobster Catch

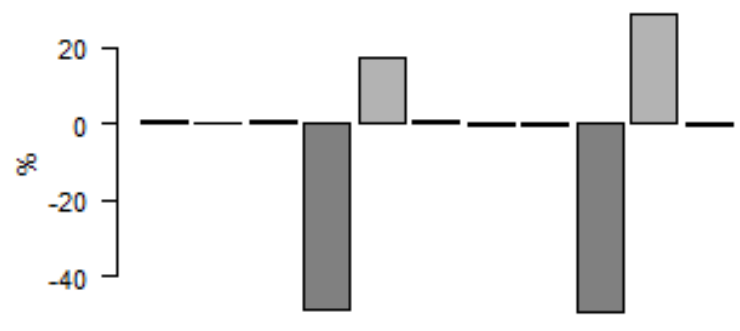

c) Fleet size

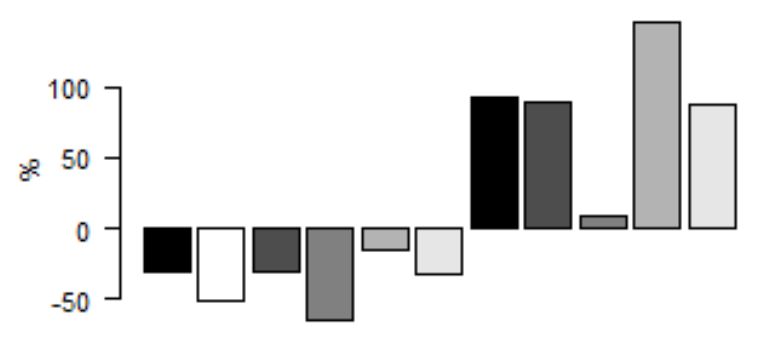

e) Crew wages

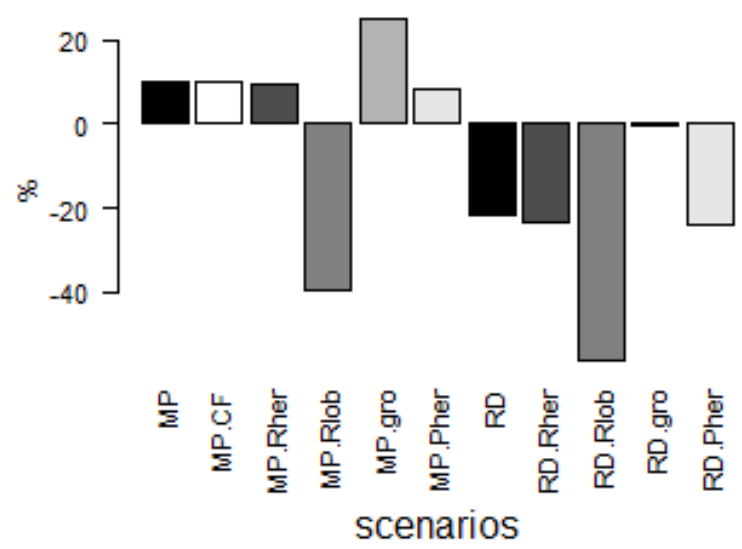

Figure 3 b) Profit

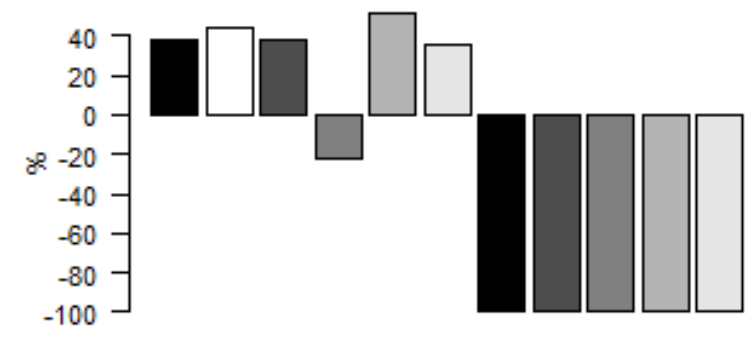

d) Lobster Biomass

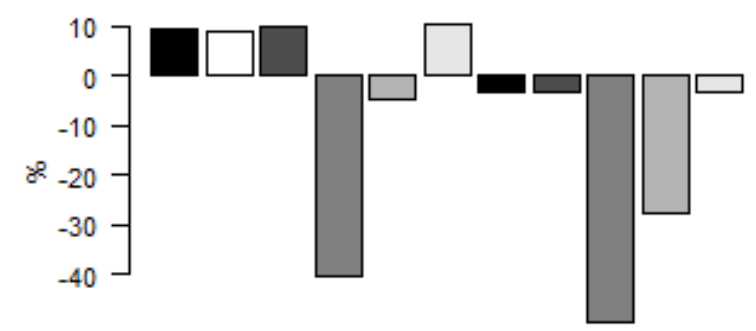

f) Captain opportunity costs

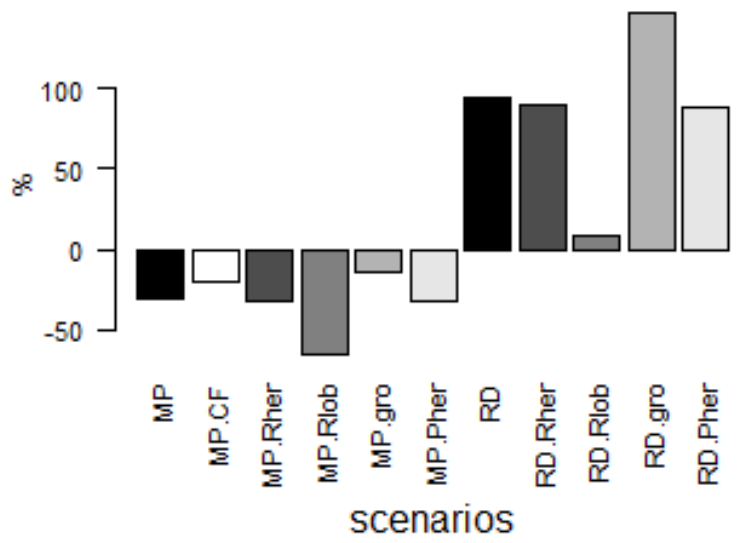


a) GoM Herring Biomass

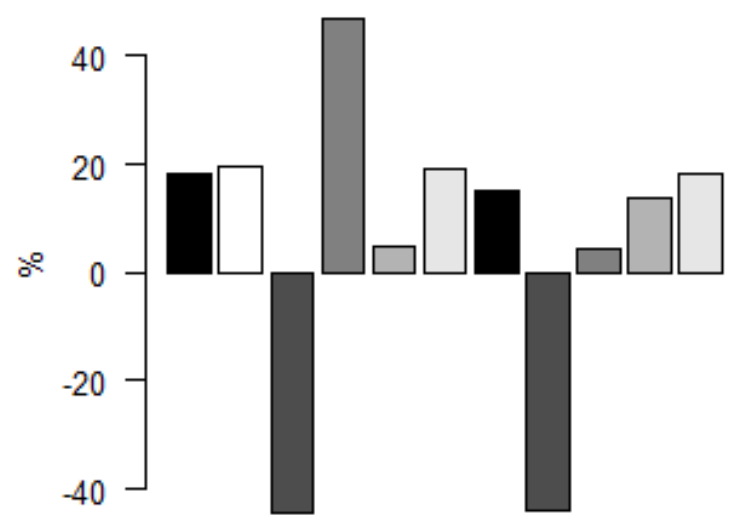

c) Herring Catch

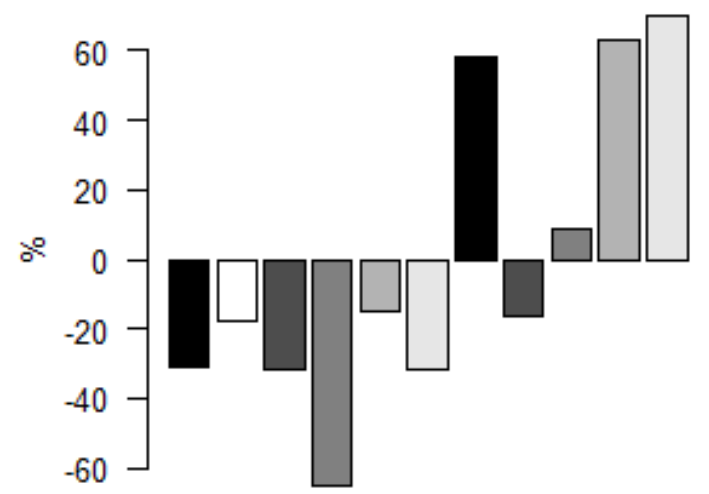

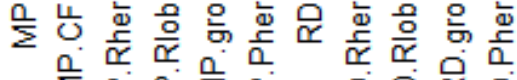

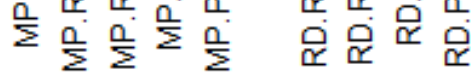

$$
\begin{aligned}
& \text { scenarios }
\end{aligned}
$$

b) GB Herring Biomass

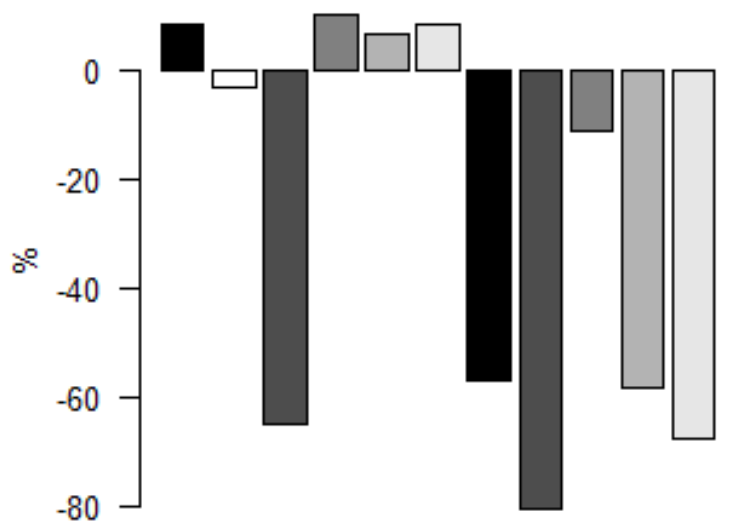

d) Percentage of substitute

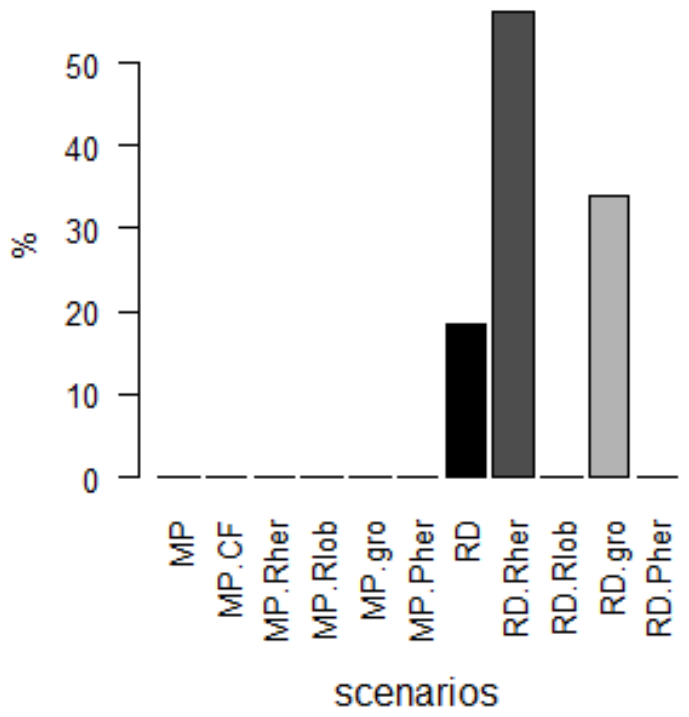

Figure 4 

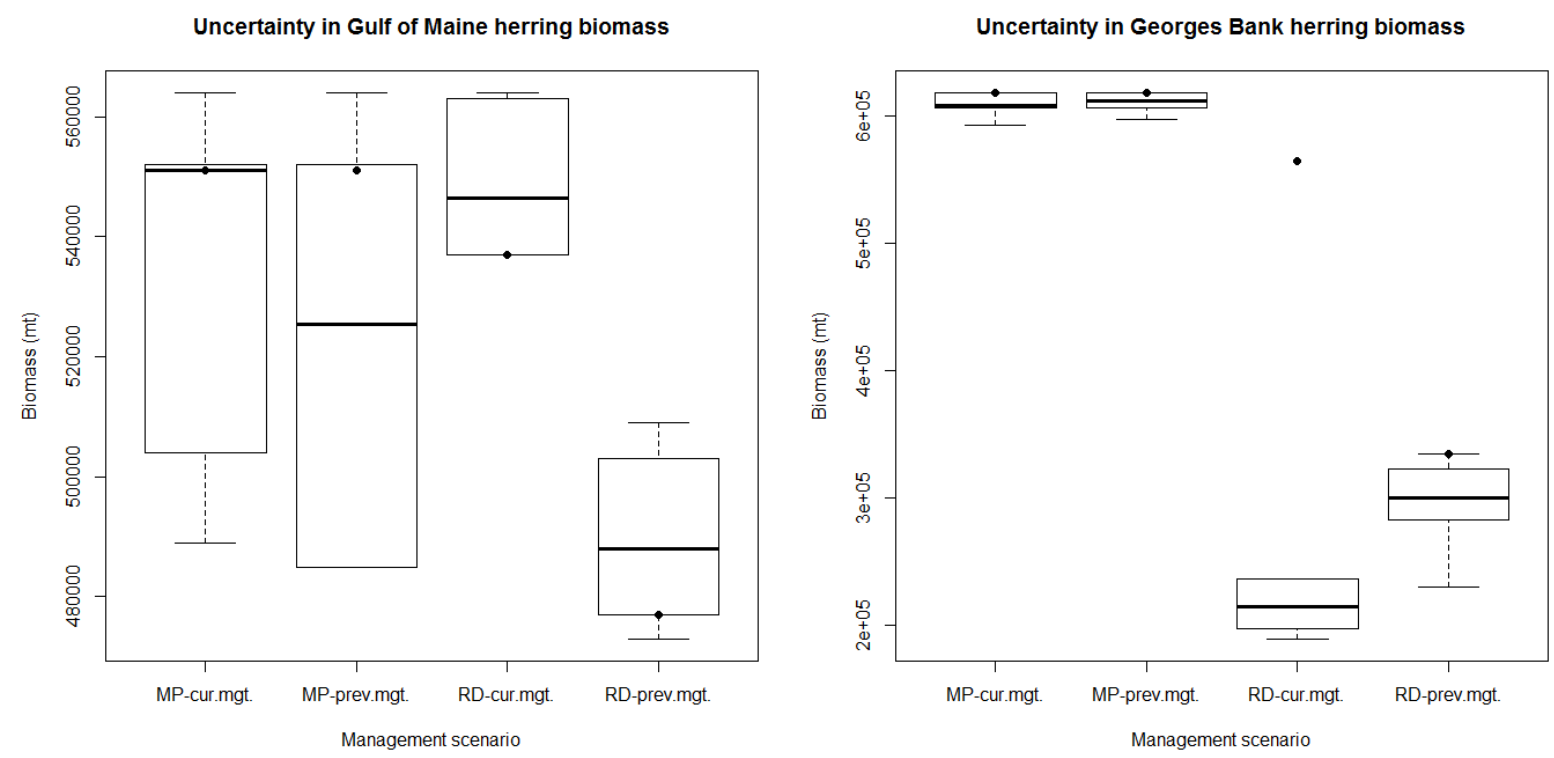

Figure 5 
Annex

Table A1: Lobster population parameters, from the assessment model (Chen and Wilson 2005)

\begin{tabular}{|c|c|}
\hline Parameter & Values \\
\hline Number of size classes & 35 \\
\hline $\begin{array}{l}\text { Distribution of recruitment over } \\
\text { the } 3 \text { first size classes }\end{array}$ & $0.66,0.33,0.01$ \\
\hline $\begin{array}{l}\text { Maturity rate / size bin (enters in } \\
\text { SSB computation) }\end{array}$ & $\begin{array}{l}0,0.001,0.002,0.008,0.024,0.074,0.202,0.447,0.72,0.891,0.963,0.98 \\
8,0.996,0.999, \text { and } 1>123 \mathrm{~mm}\end{array}$ \\
\hline $\begin{array}{l}\text { Distribution of recruitment over } \\
\text { time }\end{array}$ & $66 \%$ in July, $34 \%$ in October \\
\hline Natural mortality $\left(\mathrm{y}^{-1}\right)$ & 0.15 \\
\hline $\begin{array}{l}\text { Weight per size bin for female } \\
\text { (grams) }\end{array}$ & $\begin{array}{l}144.331,185.664,234.102,290.184,354.445,427.417,509.627,601.6 \\
04,703.87,816.948,941.356,1077.613,1226.232,1387.728,1562.613 \\
, 1751.395,1954.584,2172.687,2406.208,2655.65,2921.518,3204.31 \\
1,3504.53,3822.672,4159.235,4514.716,4889.608,5284.407,5699.6 \\
04,6135.692,6593.161,7072.501,7574.201,8098.748,8646.63\end{array}$ \\
\hline $\begin{array}{l}\text { Weight per size bin for male } \\
\text { (grams) }\end{array}$ & $\begin{array}{l}144.331,185.664,234.102,290.184,354.445,427.417,509.627,601.6 \\
04,703.87,816.948,941.356,1077.613,1226.232,1387.728,1562.613 \\
, 1751.395,1954.584,2172.687,2406.208,2655.65,2921.518,3204.31 \\
1,3504.53,3822.672,4159.235,4514.716,4889.608,5284.407,5699.6 \\
04,6135.692,6593.161,7072.501,7574.201,8098.748,8646.63\end{array}$ \\
\hline Average recruitment (number) & 77762071 \\
\hline
\end{tabular}


Table A2: Lobster economic model parameters in simulations (Holland 2011)

\begin{tabular}{|l|l|}
\hline Variable & Value \\
\hline $\begin{array}{l}\text { Monthly fleet size in historical } \\
\text { scenario }\end{array}$ & $\begin{array}{l}\text { July to June: } \\
1218,1651,1576,1466,1147,762,352,353,227,427,741,919\end{array}$ \\
\hline Trap limit & 800 \\
\hline Fuel price & $3 \$$ \\
\hline $\begin{array}{l}\text { Percent net revenue received by } \\
\text { the crews }\end{array}$ & 0.2 \\
\hline $\begin{array}{l}\text { Working hours per day for } \\
\text { lobsterman }\end{array}$ & 10 \\
\hline Fixed costs & 35000 \\
\hline Operational costs & 30000 \\
\hline Captain's hour wage & 15 \\
\hline Fuel used per trap haul & $\begin{array}{l}\text { Winter }(1-5): 0.1345 \text { gallons } \\
\text { Summer }(6-12): 0.866 \text { gallons }\end{array}$ \\
\hline Trap hauls per day & 250 \\
\hline $\begin{array}{l}\text { Simulated haul days per month } \\
\text { (per lobsterman) }\end{array}$ & $\begin{array}{l}20 \\
\text { Or model }\end{array}$ \\
\hline Bait per trap & $\begin{array}{l}\text { Winter }(1-5): 2.84 \mathrm{lb} ; \text { Summer }(6-12): 2.3 \mathrm{lb} \\
\text { Or model }\end{array}$ \\
\hline Soak days per trap & July to June: $4,4,4,5,6,8,8^{1}, 8^{1}, 8^{1}, 6,5,5$ \\
\hline US personal income in billions & 13281 \\
\hline US population in millions & 313414 \\
\hline Real growth in GDP & $3 \%$ \\
\hline Exchange rate with Canada & 1 \\
\hline 1
\end{tabular}

${ }^{1}$ the monthly average for January-March are based on very few observations because the port sampling program has not generally operated during the period, therefore the values for those months have been replaced with the value assessed for December. 
Table A3: Lobster production function parameters ${ }^{1}$

\begin{tabular}{|c|c|c|c|}
\hline Variables & Estimates & $\begin{array}{l}\text { Std. } \\
\text { error }\end{array}$ & $\begin{array}{c}\text { Significance level } \\
\text { (p-value }<=00^{\prime * * * \prime} ; 0.001^{\prime * * \prime} ; \\
\left.0.01^{(* \prime} ; 0.05^{\prime} .^{\prime}\right)\end{array}$ \\
\hline Constant & -121.90 & 21.02 & $* * *$ \\
\hline JAN & 0.00 & & Not selected \\
\hline FEB & 0.00 & & Not selected \\
\hline MAR & 0.00 & & Not selected \\
\hline APR & 0.33 & 0.09 & $* * *$ \\
\hline MAY & 0.59 & 0.12 & $* * *$ \\
\hline JUN & 1.01 & 0.10 & $* * *$ \\
\hline JUL & 1.31 & 0.10 & $* * *$ \\
\hline AUG & 1.31 & 0.10 & $* * *$ \\
\hline SEP & 1.38 & 0.10 & $* * *$ \\
\hline OCT & 1.33 & 0.10 & $* * *$ \\
\hline NOV & 1.09 & 0.10 & $* * *$ \\
\hline DEC & 0.81 & 0.19 & $* * *$ \\
\hline Log(Total Hauls) & 0.31 & 0.09 & $* * *$ \\
\hline Log(Soak Days) & & & Not selected \\
\hline Log(Total Hauls in ME) & 14.05 & 2.43 & $* * *$ \\
\hline Log( Monthly Biomass) & 0.50 & 0.02 & $* * *$ \\
\hline Log(Bait per trap) & 0.03 & 0.02 &. \\
\hline Log(Total Hauls)^2 & -0.11 & 0.03 & $* * *$ \\
\hline Log(Soak Days)^2 & -0.01 & 0.00 & $* * *$ \\
\hline Log(Total Hauls in ME)^2 & -0.40 & 0.07 & $* * *$ \\
\hline Log(Monthly Biomass)^2 & & & Not selected \\
\hline Log(Total Hauls)*Log(Total Hauls in ME) & & & Not selected \\
\hline Log(Monthly Biomass)*Log(Total Hauls) & & & Not selected \\
\hline Log(Total Hauls)* $\log ($ Bait per trap) & & & Not selected \\
\hline Log(Total Hauls in ME)*Log(Soak Days) & & & Not selected \\
\hline Log(Monthly Biomass)*Log(Soak Days) & & & Not selected \\
\hline Log(Bait per trap)* Log(Soak Days) & & & Not selected \\
\hline Log(Monthly Biomass)*Log(Total Hauls in ME) & & & Not selected \\
\hline Log(Bait)^2 & & & Not selected \\
\hline
\end{tabular}

${ }^{1}$ The variables were selected through a stepwise procedure based on AIC (step procedure, R software). The variables not selected by the procedure are shown in the table for information, but were dropped in the model, except for the effect of some months that were set to zero instead. 
Table A4: Herring population parameters

\begin{tabular}{|l|l|l|}
\hline Herring parameters & Parameter value & reference \\
\hline $\begin{array}{l}\text { Average recruitment in each } \\
\text { stock (numbers) }\end{array}$ & $\begin{array}{l}\text { GoM: } 1.38 \mathrm{e} 9 \\
\text { GB: } 1.05 \mathrm{e} 9\end{array}$ & Shepherd et al. 2009 \\
\hline Natural mortality & 0.2 & Shepherd et al. 2009 \\
\hline $\begin{array}{l}\text { Catch at age proportions (2-6 } \\
\text { years old) }\end{array}$ & $0.085,0.251,0.312,0.222,0.131$ & $\begin{array}{l}\text { Assessment based on catch at } \\
\text { age and abundance at age data } \\
\text { (2005-2008), Shepherd et al. } \\
2009\end{array}$ \\
\hline $\begin{array}{l}\text { Average weight at age } \mathbf{( k g ) ~ ( 2 - 6} \\
\text { years old) }\end{array}$ & $0.032,0.066,0.104,0.136,0.177$ & $\begin{array}{l}\text { Assessment based on weight } \\
\text { and age sampling, NOAA, BTS } \\
\text { fall surveys 1989-2008 }\end{array}$ \\
\hline $\begin{array}{l}\text { Maturity rate at age (2-6 years } \\
\text { old) }\end{array}$ & $0.21,0.86,0.93,0.98,1$ & Shepherd et al. 2009 \\
\hline
\end{tabular}


Table A5: Herring migration pattern. From NEFMC 2010. The second number corresponds to the alternative assumption in the uncertainty analysis.

\begin{tabular}{|c|c|c|c|c|c|c|c|c|c|}
\hline & & \multicolumn{8}{|l|}{ From } \\
\hline & \multirow[b]{2}{*}{ stock } & \multicolumn{2}{|l|}{ Area 1A } & \multicolumn{2}{|l|}{ Area1B } & \multicolumn{2}{|l|}{ Area2 } & \multicolumn{2}{|l|}{ Area3 } \\
\hline & & GoM & GB & GoM & GB & GoM & GB & GoM & GB \\
\hline \multirow[t]{4}{*}{ To } & Area1A & & & & & $\begin{array}{l}\text { Apr: } \\
0.6 / 0.35\end{array}$ & $\begin{array}{l}\text { Apr: } \\
0.125 / 0.25\end{array}$ & & \\
\hline & Area1B & & & & & $\begin{array}{l}\text { Apr: } \\
0.4 / 0.27\end{array}$ & $\begin{array}{l}\text { Apr: } \\
0.125 / 0.25\end{array}$ & & \\
\hline & Area2 & $\begin{array}{l}\text { Dec: } \\
0.8 / 0.83 \\
\text { Aug: /0.49 }\end{array}$ & & $\begin{array}{l}\text { Dec: } \\
0.8 / 0.67 \\
\text { Aug: /0.51 }\end{array}$ & & & & & $\begin{array}{l}\text { Dec: } \\
0.95 / 887\end{array}$ \\
\hline & Area3 & & $\begin{array}{l}\text { Aug: } \\
1\end{array}$ & & $\begin{array}{l}\text { Aug: } \\
1\end{array}$ & & $\begin{array}{l}\text { Apr: } \\
0.62 / 0.20 \\
\text { Aug: } 1\end{array}$ & & \\
\hline
\end{tabular}


Table A6: Herring management parameters

\begin{tabular}{|c|c|c|c|c|c|}
\hline Parameter & \multicolumn{4}{|l|}{ Value } & reference \\
\hline Fmsy & \multicolumn{4}{|l|}{0.24} & \multirow[t]{5}{*}{ NEFMC 2010} \\
\hline Management buffer & \multicolumn{4}{|l|}{0.6} & \\
\hline \multirow[t]{2}{*}{ NB weir fishery uncertainty } & \multicolumn{4}{|c|}{$\begin{array}{l}14800 \mathrm{mt} \text { (average Canadian catch from 1999- } \\
2008 \text { ) }\end{array}$} & \\
\hline & Area $1 \mathrm{~A}$ & Area 1B & Area 2 & Area 3 & \\
\hline TAC proportion per area & $\begin{array}{l}0.29 / \\
0.35\end{array}$ & $\begin{array}{l}0.05 / \\
0.06\end{array}$ & $\begin{array}{l}0.24 / \\
0.295\end{array}$ & $\begin{array}{l}0.42 / \\
0.295\end{array}$ & \\
\hline Max effort per month & \multicolumn{4}{|l|}{$30 \mathrm{j}$} & \\
\hline
\end{tabular}


Table A7: Herring production function parameters

\begin{tabular}{|l|l|l|l|}
\hline Gear and area & parameter & estimate & p-value \\
\hline Area 1A & $\mathrm{a}$ & $1.07 \mathrm{e}-3$ & $<0.01$ \\
\cline { 2 - 4 } Pair trawler & $\mathrm{b}$ & $3.63 \mathrm{e}-4$ & $<0.01$ \\
\hline Area 1B & $\mathrm{a}$ & $9.753 \mathrm{e}-4$ & 0.128 \\
\hline Pair trawler & $\mathrm{b}$ & $3.62 \mathrm{e}-4$ & 0.156 \\
\hline $\begin{array}{l}\text { Area 2 } \\
\text { Pair trawler }\end{array}$ & $\mathrm{a}$ & $2.40 \mathrm{e}-2$ & 0.769 \\
\hline Area 3 & $\mathrm{b}$ & $1.22 \mathrm{e}-2$ & 0.77 \\
\hline Pair trawler & $\mathrm{a}$ & $1.63 \mathrm{e}-4$ & 0.028 \\
\hline Area 1A & $\mathrm{B}$ & $7.75 \mathrm{e}-5$ & 0.044 \\
\hline Purse seiner & $\mathrm{a}$ & $1.388 \mathrm{e}-4$ & 0.263 \\
\cline { 2 - 4 } & $\mathrm{b}$ & $4.925 \mathrm{e}-5$ & 0.0582 \\
\hline
\end{tabular}


Table A8: Herring fishery costs

\begin{tabular}{|l|l|l|l|l|l|l|}
\hline & $\begin{array}{l}\text { Fuel costs } \\
\text { per hour } \\
(\mathbf{\$} / \mathbf{h})\end{array}$ & $\begin{array}{l}\text { Food costs } \\
\text { per hour } \\
\mathbf{( \$ / h )}\end{array}$ & $\begin{array}{l}\text { Supply costs } \\
\text { per hour } \\
\mathbf{( \$ / h )}\end{array}$ & $\begin{array}{l}\text { Damage } \\
\text { costs per } \\
\text { hour } \mathbf{( \$ / h )}\end{array}$ & Crew share & $\begin{array}{l}\text { Fixed costs } \\
\text { per year } \mathbf{( \$ )}\end{array}$ \\
\hline $\begin{array}{l}\text { Purse } \\
\text { seiners }\end{array}$ & 65.67 & 7.43 & 2.25 & 4.47 & 0.35 & 600000 \\
\hline $\begin{array}{l}\text { Pair } \\
\text { trawlers }\end{array}$ & 93.21 & 5.6 & 0.54 & 22.58 & 0.35 & 600000 \\
\hline
\end{tabular}


Table A9: Herring transportation costs to Portland, Me

\begin{tabular}{|l|l|l|l|l|}
\hline & Area 1A & Area 1B & Area 2 & Area 3 \\
\hline $\begin{array}{l}\text { Transportation } \\
\text { costs }(\mathbf{\$} / \mathbf{l b})\end{array}$ & 0.01 & 0.013 & 0.027 & 0.013 \\
\hline
\end{tabular}




\begin{tabular}{|c|c|c|c|c|c|c|c|c|c|c|c|c|}
\hline Effort & $\begin{array}{l}\text { Bait } \\
\text { effect } \\
\text { on } \\
\text { growth } \\
\end{array}$ & $\begin{array}{l}\text { Herring } \\
\text { management }\end{array}$ & & $\begin{array}{l}\text { Lobster } \\
\text { catch } \\
\text { (mt) }\end{array}$ & $\begin{array}{l}\text { Economic } \\
\text { profit } \\
(\mathrm{k} \$)\end{array}$ & $\begin{array}{l}\text { Total } \\
\text { wages } \\
\text { (k\$) }\end{array}$ & $\begin{array}{l}\text { Fleet } \\
\text { size }\end{array}$ & $\begin{array}{l}\text { Lobster } \\
\text { biomass } \\
\text { (mt) }\end{array}$ & $\begin{array}{l}\text { GoM } \\
\text { Herring } \\
\text { biomass } \\
\text { (mt) }\end{array}$ & $\begin{array}{l}\text { GB } \\
\text { Herring } \\
\text { biomass } \\
\text { (mt) }\end{array}$ & $\begin{array}{l}\text { Herring } \\
\text { catch } \\
\text { (mt) }\end{array}$ & $\begin{array}{l}\text { Substitute } \\
\text { bait use } \\
\text { (mt) }\end{array}$ \\
\hline \multirow{12}{*}{$\begin{array}{c}\text { Profit } \\
\text { maximisation }\end{array}$} & \multirow{6}{*}{$\begin{array}{l}\text { Base } \\
\text { case }\end{array}$} & \multirow{3}{*}{ Current } & Base case & 30393 & 182628 & 82987 & 1136 & 85104 & 551411 & 618134 & 40173 & 0 \\
\hline & & & Alt. CPUE & 30395 & 182238 & 82830 & 1135 & 85184 & 551857 & 618168 & 40109 & 0 \\
\hline & & & Alt. Migration & 30392 & 182643 & 82993 & 1136 & 85101 & 563505 & 606021 & 40176 & 0 \\
\hline & & \multirow{3}{*}{ Alternative } & Base case & 30393 & 182628 & 82987 & 1136 & 85104 & 551411 & 618134 & 40173 & 0 \\
\hline & & & Alt. CPUE & 30395 & 182238 & 82830 & 1135 & 85184 & 551857 & 618168 & 40109 & 0 \\
\hline & & & Alt. Migration & 30392 & 182643 & 82993 & 1136 & 85101 & 563505 & 606021 & 40176 & 0 \\
\hline & \multirow{6}{*}{$\begin{array}{c}\text { Bait } \\
\text { effect } \\
\text { on } \\
\text { growth }\end{array}$} & \multirow{3}{*}{ Current } & Base case & 35423 & 200309 & 96374 & 1409 & 85104 & 551411 & 607694 & 49823 & 0 \\
\hline & & & Alt. CPUE & 35423 & 199333 & 96130 & 1409 & 74141 & 489437 & 607707 & 49823 & 0 \\
\hline & & & Alt. Migration & 35423 & 200334 & 96380 & 1409 & 74138 & 504273 & 592858 & 49823 & 0 \\
\hline & & \multirow{3}{*}{ Alternative } & Base case & 35423 & 200329 & 96379 & 1409 & 74133 & 484951 & 612158 & 49823 & 0 \\
\hline & & & Alt. CPUE & 35423 & 199342 & 96132 & 1409 & 74136 & 484964 & 612159 & 49823 & 0 \\
\hline & & & Alt. Migration & 35423 & 200357 & 96386 & 1409 & 74134 & 500372 & 596739 & 49823 & 0 \\
\hline \multirow{12}{*}{$\begin{array}{c}\text { Rent } \\
\text { dissipation }\end{array}$} & \multirow{6}{*}{$\begin{array}{l}\text { Base } \\
\text { case }\end{array}$} & \multirow{3}{*}{ Current } & Base case & 30118 & 0 & 105071 & 3198 & 75128 & 536915 & 563505 & 92323 & 20751 \\
\hline & & & Alt. CPUE & 30116 & 0 & 103791 & 3160 & 75150 & 548179 & 189339 & 88377 & 23320 \\
\hline & & & Alt. Migration & 30118 & 0 & 105004 & 3196 & 75129 & 562906 & 222103 & 91898 & 21104 \\
\hline & & \multirow{3}{*}{ Alternative } & Base case & 30118 & 0 & 105209 & 3203 & 75125 & 476567 & 334146 & 88483 & 24740 \\
\hline & & & Alt. CPUE & 30117 & 0 & 104486 & 3181 & 75138 & 483521 & 282410 & 96232 & 16213 \\
\hline & & & Alt. Migration & 30118 & 0 & 105176 & 3202 & 75126 & 503492 & 307233 & 88482 & 24705 \\
\hline & \multirow{6}{*}{$\begin{array}{c}\text { Bait } \\
\text { effect } \\
\text { on } \\
\text { growth }\end{array}$} & \multirow{3}{*}{ Current } & Base case & 38787 & 0 & 133615 & 4067 & 75128 & 536915 & 236302 & 94965 & 48828 \\
\hline & & & Aalt. CPUE & 37837 & 0 & 129763 & 3950 & 55299 & 545430 & 196817 & 103298 & 35806 \\
\hline & & & Alt. Migration & 38788 & 0 & 133547 & 4065 & 56228 & 564375 & 207294 & 95340 & 48380 \\
\hline & & \multirow{3}{*}{ Alternative } & Base case & 41949 & 0 & 142622 & 4342 & 57661 & 473408 & 322484 & 93152 & 60334 \\
\hline & & & Alt. CPUE & 38789 & 0 & 132816 & 4043 & 56243 & 491683 & 229525 & 101247 & 41522 \\
\hline & & & Alt. Migration & 41949 & 0 & 142555 & 4340 & 57662 & 508510 & 292079 & 92477 & 60937 \\
\hline
\end{tabular}

Table A10: Results of the sensitivity analysis on nine output variables 